Discussion Papers

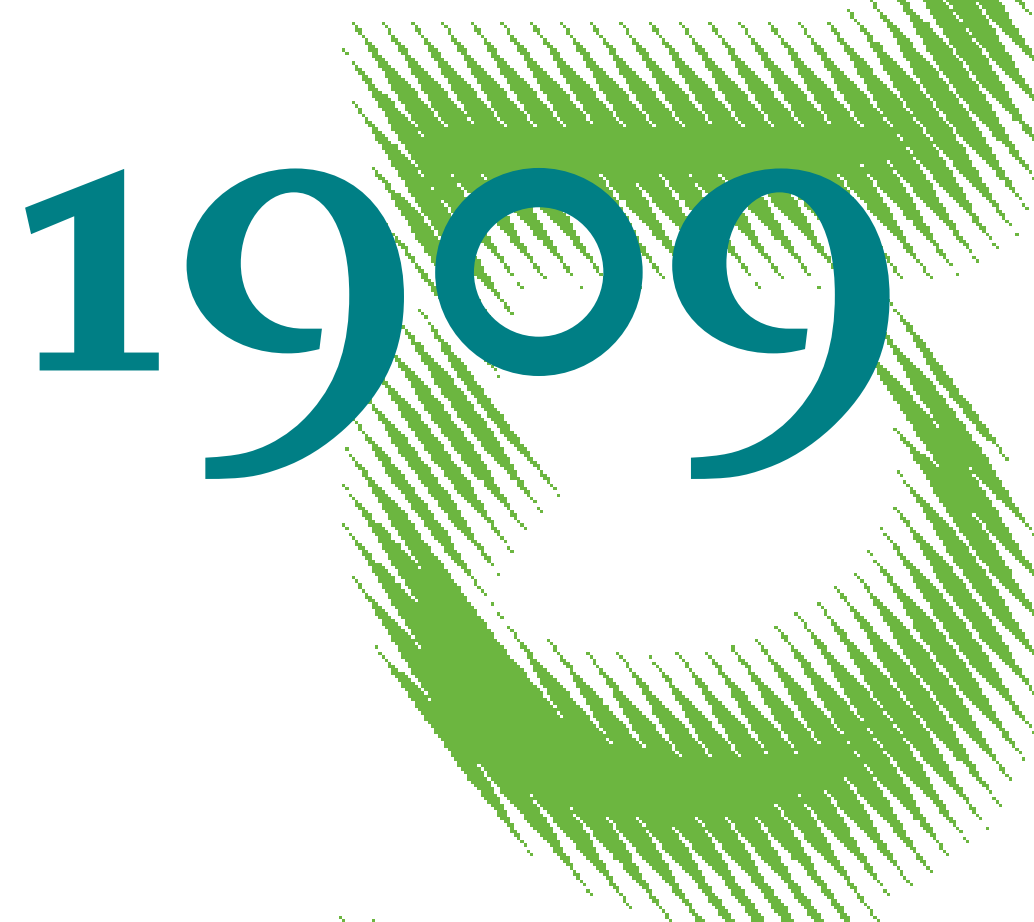

Kurzarbeit and Natural Disasters: How Effective Are Short-Time Working Allowances in Avoiding Unemployment? 
Opinions expressed in this paper are those of the author(s) and do not necessarily reflect views of the institute.

IMPRESSUM

(C) DIW Berlin, 2020

DIW Berlin

German Institute for Economic Research

Mohrenstr. 58

10117 Berlin

Tel. +49 (30) $89789-0$

Fax +49 (30) $89789-200$

http://www.diw.de

ISSN electronic edition 1619-4535

Papers can be downloaded free of charge from the DIW Berlin website:

http://www.diw.de/discussionpapers

Discussion Papers of DIW Berlin are indexed in RePEc and SSRN:

http://ideas.repec.org/s/diw/diwwpp.html

http://www.ssrn.com/link/DIW-Berlin-German-Inst-Econ-Res.html 


\title{
Kurzarbeit and natural disasters: How effective are short-time working allowances in avoiding unemployment?
}

\author{
Julio G. Fournier Gabela ${ }^{a, b, *}$ \\ Luis Sarmiento ${ }^{a}$
}

November 2, 2020

${ }^{a}$ DIW Berlin, Mohrenstrasse 58, 10117 Berlin, Germany

${ }^{b}$ Humboldt Universität zu Berlin, Unter den Linden 6, 10099 Berlin, Germany

There is substantial evidence on the effectiveness of short-time work on reducing unemployment. However, no study looks at its role during natural disasters. This article exploits the exogenous nature of the 2013 European floods to assess if the impact depends on the quality of the short-time work mechanism across affected counties. We use regression discontinuity designs to show that unemployment does not increase in regions with robust programs while rising up to seventeen percent in areas with less robust mechanisms. Our results are relevant to the literature on how institutional quality influences recovery and suggests that short-time work programs are useful against unforeseeable productivity shocks besides financial crises.

JEL codes: J68, H84, Q54, C22

Keywords: Flooding, short-time work, regional unemployment, regression discontinuity in time, institutions

Declarations of interest: none

*juliofournier@aol.com, corresponding author 


\section{Introduction}

2 In May and June 2013, extreme precipitation caused many Central European rivers to 3 overflow, inundating several urban, industrial, and agricultural areas across Austria, 4 the Czech Republic, Germany, Hungary, and Slovakia. Studies of this event show 5 evidence of its effects on the transportation network (Fournier Gabela and Sarmiento, 2020), industrial production (in den Bäumen et al., 2015; Oosterhaven and Többen, 2017), insurance claims (Munich RE, 2014), and general infrastructure (Thieken et al., 2016). Following the literature on how institutions can influence recovery after a natu9 ral disaster (Cavallo et al., 2013; Barone and Mocetti, 2014), in this article, we exploit 10 differences in short-time work programs across affected nations to understand the abil11 ity of these mechanisms to dampen the adverse consequences of natural disasters on 12 employment. ${ }^{1}$

13 Natural disasters decrease the productivity of firms through several channels, in14 cluding capital destruction, supply chain interruptions, and demand-side pressures. 15 Lower productivity forces affected companies to reduce their labor demand (total work 16 hours) through layoffs (extensive margin) or reduced working time (intensive margin). ${ }_{17}$ The absence of wage support mechanisms promoting adjustments via the intensive 18 margin can lead to inefficient separations and unequal distribution of uncertainty 19 among the workforce (Van Audenrode, 1994; Arpaia et al., 2010). Short-time work 20 programs aim to stabilize labor markets by avoiding involuntary dismissals, fostering 21 labor hoarding, and encouraging work-sharing. They work through direct government 22 transfers providing wage support to firms in financial distress and are complements to 23 other working-time flexibility instruments. ${ }^{2}$ However, compared to other alternatives, 24 short-time work provides help to firms in financial difficulties by freeing them from 25 paying wages for non-worked hours. It is a substitute for labor adjustments via the 26 extensive margin and a superior strategy depending on the nature of the shock (Rinne 27 and Zimmermann, 2012).

${ }_{28} \quad$ Studying the adequacy of short-time work mechanisms under different conditions

\footnotetext{
${ }^{1}$ Alternative names for short-time work programs are short-time compensation systems and job retention schemes.

${ }^{2}$ In Germany and Austria, firms must first exhaust alternative flexibility instruments before commencing short-time work (Eurofound, 2010a).
} 
is essential for improving future program design. For instance, gained insights can help orientate efforts to alleviate the impacts of other types of catastrophes, such as the COVID-19 outbreak. Furthermore, studies on the economic consequences of repetitive events, like floods, are highly relevant because climate change will exacerbate both the frequency and intensity of natural disasters around the globe (IPCC, 2012). In particular, climate change is likely to increase the number of Central European floods because of its effect on European weather patterns (Jongman et al., 2014).

Existing studies on the effect of natural disasters on unemployment find negative impacts in affected regions during the immediate aftermath of the disaster Belasen and Polachek, 2008; Ewing et al., 2009; Xiao and Feser, 2014; Brown, 2006). Natural disasters affect labor markets because physical damage can hinder normal working conditions while creating structural changes, mismatches between workers and firms, as well as barriers to the demand and supply of labor (Venn, 2012). Examples include the evacuation of people, workers who cannot arrive at work, the incapacity to work because of damage to buildings or machinery, as well as firms that cannot operate because of supply chain problems.

Early contributions on the labor market effects of short-time work indicate that German firms using this instrument display less employment volatility (Deeke, 2005). Abraham and Houseman (1993); Van Audenrode (1994) show that countries with generous short-time work programs achieve a high speed of adjustment in total working hours to changes in output. ${ }^{3}$ This is possible because short-time work effectively compensates for firing restrictions consequence of strict employment protection legislation. The strictness of employment protection increases the probability of participating in short-time work programs, while the generosity of unemployment benefits works in the opposite direction (Van Audenrode, 1994; Boeri and Bruecker, 2011; Cahuc and Carcillo, 2011). Although the average contribution of the intensive margin to Germany's labor adjustment was close to $50 \%$ during historic recessions, the use of these adjustments reached unprecedented levels during the 2008 financial crisis in this country and other advanced nations (Boeri and Bruecker, 2011).

\footnotetext{
${ }^{3}$ The level of generosity refers to workers' current income under short-time work as a percentage of their previous (regular) income.
} 


\footnotetext{
${ }^{4}$ Hoffmann and Lemieux (2016) show that there is no German miracle when using data until 2011. However, there is still a German puzzle: employment barely declined early in the crisis despite a sharp fall of GDP.

${ }^{5}$ Full-time equivalents are a fictitious number giving the potential number of full- and part-time jobs saved due to the implementation of short-time work.

${ }^{6}$ In Germany, working time reductions are possible thanks to sector-specific opening clauses that allow for non-compensated working hours reductions up to $25 \%$ (Bispinck, 2009).
} 


\footnotetext{
${ }^{7}$ Other popular extensive margin instruments include letting fixed-term contract expire, stop hiring, and early retirement schemes (Bogedan et al., 2009).
} 


\footnotetext{
${ }^{8}$ Generosity and experience also raise participation rates for other social programs (McLaughlin,
} 1987; Hernanz et al., 2004).

first time during the 2008 financial crisis, Hungary did not have any active program in 2013. Further, while Austria, Germany, and Slovakia share similarities concerning the strictness of employment protection and unemployment benefits, the institutional setting impedes (facilitates) extensive margin adjustments in the Czech Republic (Hungary).

This study is the first examining the effectiveness of short-time work programs for shocks other than the 2008 financial crisis. Can a labor market instrument capable of saving hundreds of thousands of jobs throughout economic crises prevent unemployment during a natural disaster? Given the shock characteristics of the 2013 floods and evidence indicating that nations with robust short-time work programs (Boeri and Bruecker, 2011; Cahuc and Carcillo, 2011; Rinne and Zimmermann, 2012) and experience in implementation (Boeri and Bruecker, 2011; Rinne and Zimmermann, 2012) achieve higher participation rates, we propose that different labor market outcomes in each of the flooded countries are due to differences in the program features. ${ }^{8}$

To estimate the floods' impact, we use a local-linear regression discontinuity in time (RDiT) design (Hausman and Rapson, 2018). Studies employing a similar quasiexperimental approach include several areas such as transportation (Anderson, 2014; Burger et al., 2014), health (Toro et al., 2015), and environmental economics (Grainger and Costello, 2014). Compared to the traditional regression discontinuity design, RDiT uses time as the running and treatment assignment variables. In other words, it estimates the discontinuity in the flooded month by comparing the dependent variables just before and after it. To avoid bias from correlated temporal unobservables, we use the augmented version of RDiT (ARDiT), as suggested in Hausman and Rapson (2018). The main idea behind the ARDiT is to divide the estimation procedure into two steps, one initial regression taking away the time variation in the dependent variable and a second regression using the residuals from the first step in a RDiT framework. It is necessary to use an ARDiT specification because using variables over a large time window increases the risk of having biased estimates arising from unobserved time-varying factors. We test for the robustness of the design with a placebo 
test studying the effect of the flood on unaffected European countries.

We begin by exploring the effect of the floods on short-time work participation in Germany. The results show that companies and employees in Germany actively used the short-time work mechanism during the floods; the number of short-time companies and the number of short-time employees increasing by $29 \%$ and $25 \%$, respectively. Afterward, we examine how the inundations affected the unemployment rates of five Central European countries afflicted by the floods. In line with our expectations, countries with robust programs suffered no significant effects while uncovering negative consequences for the other affected Central European countries. For the Czech Republic, Hungary, and Slovakia, the flood increases regional unemployment in flooded counties by $7 \%, 9 \%$, and $6 \%$, respectively. To determine if the German labor market's stability is related to its robust short-time work program, we re-estimate the flood effects for all variables using different flood extent intensities. As we reduce the sample to include only those regions with a larger flooded area, we find that Germany's short-time work participation increases further up to $75 \%$. As expected, while unemployment remains unaffected in Germany and Austria, it further increases to $14 \%, 17 \%$, and $9 \%$ in the other flooded countries, respectively.

Our findings suggest that well-designed short-time work programs can flatten the negative impact of natural disasters on employment, implying that these programs can also be useful in the case of short-lived events, including famines, pandemics, or terrorist attacks. Our findings support arguments in favor of implementing short-time work programs in countries where they do not exist and to the adjustment of already implemented programs during periods of unforeseeable productivity shocks.

\section{Background}

\subsection{Theoretical background}

\subsubsection{A labor market model under disaster risk}

To provide intuition into the effect of unexpected natural disasters on unemployment and describe how short-time work programs can support labor markets in adjusting 
against these types of shocks, we develop a simplified model with endogenous job separations arising from natural disaster shocks. The model is based on the Diamond (1982) and Mortensen and Pissarides (1994) search and matching frictions framework, which is also used by Cooper et al. (2017) and Balleer et al. (2016) to study the effects of short-time work.

In this model, employed and unemployed make up the labor force $L$. Workers are homogeneous, risk-neutral, immortal, and their utility evolves linearly with wages. Each firm needs only one worker to produce. However, each firm's production process is subject to exogenous natural disaster shocks, which reduce the firm's productivity through several channels, including capital destruction, supply chain interruptions, decreases in demand, and labor supply restrictions. The disaster shock $\gamma$ affects the firm's productivity $p(h)$ through $(1-\gamma) \cdot p(h)$. The larger the $\gamma$ coefficient, the larger the productivity reduction. We assume that $\gamma$ is a random variable drawn from a fixed and strictly increasing distribution $F(\gamma) \forall \gamma \in[\underline{\gamma}, \bar{\gamma}]$. The lower end of the interval equals zero, thus denoting the absence of a disaster shock. The upper end equals one. A cut-off shock value $\tilde{\gamma}$ determines job destruction such that whenever $\gamma>\tilde{\gamma}$, the firm will destroy the match. $\lambda$ denotes the Poisson probability that the shock hits a job match.

The initial labor market equilibrium defines the overall levels of unemployment $u$, job creation, optimal working hours $h$, wages $\omega(h, \gamma)$, and the firing threshold $\tilde{\gamma}$. Note that the initial equilibrium is defined in the absence of disaster shocks, that is, at $\gamma=\gamma$ and, hence, with the greatest possible productivity. Furthermore, firms can adjust the number of working hours instantaneously and without any constraint. In Appendix A, we derive the full equilibrium conditions and provide additional details.

\subsubsection{Equilibrium under hours constraint and short-time work}

To show how short-time work programs help labor markets reduce labor agreements' destruction in the face of an exogenous disaster shock, we show how increasing the generosity of short-time work mechanisms increases the model's endogenous firing threshold. An increase in this threshold means that the disaster shock must be more severe for a firm to destroy a job match or, equivalently, reduces the probability of 
match destruction. Consequently, the impact that a natural disaster exerts on overall unemployment is smaller than in a scenario with less generous short-time work mechanisms.

In the new equilibrium, firms realize disaster shocks and decide whether or not to destroy job matches according to the firing threshold $\tilde{\gamma}$ defined in the initial equilibrium by setting $r J(\tilde{\gamma})=0$. We assume that wages $\bar{\omega}$ remain as in the initial equilibrium. These are affected neither by the shocks nor by the short-time work policy. Furthermore, following Cooper et al. (2017), we assume that contractual working hours $\underline{h}$ impose a lower threshold to the optimal number of hours a firm can set, $h \geq \underline{h}$. These restrictions reflect a short-term scenario of wage rigidities and the absence of working time flexibility instruments typically enforced by employment protection laws.

Let us define a short-time work program as $\mathcal{S} \mathscr{T} \mathfrak{W}=\left\{\Xi, \xi_{f}, \xi_{w}\right\}$. The first policy component refers to the number of permissible hours reductions, with $0<\Xi \leq \underline{h}$. While $\Xi=0$ represents a case without a short-time work policy, $\Xi=\underline{h}$ represents the most generous case of full hours coverage. The other two components refer to the level of government wage compensation of non-worked hours received by firms and workers, respectively, with $0<\xi_{f}, \xi_{w} \leq 1$. The upper end represents the maximum possible generosity level since employees and firms will receive a full salary compensation for non-worked hours.

The first policy component loosens the contractual hour constraint such that each firm is now allowed to set hours subject to $h \geq \underline{h}-\Xi$. Equation 1 gives the corresponding firm's decision on the number of optimal hours. According to it, a firm will choose the highest value from two options: the binding constraint given by $\underline{h}$ minus the number of permissible hour reductions and the optimal working hours from the initial equilibrium.

$$
h^{*}=\max \left\{\underline{h}-\Xi,\left[\frac{\Omega_{h}\left(h^{*}\right)}{\alpha(1-\gamma)}\right]^{\frac{1}{\alpha-1}}\right\}
$$

The value functions for workers and jobs are given by equations 2 and 3 , respectively. According to the first, workers receive income from the new optimal number 
of hours plus a share $\xi_{w}$ of the difference between contractual and new optimal hours, that is, non-worked hours. $\Omega(h)$ stands for the dis-utility of labor and the last term in the equation is the worker surplus. Similarly, the new present discounted value of a job now depends on the new optimal number of hours plus a share $\xi_{f}$ of the nonworked hours. The last term in the equation is the job surplus after using the free entry condition $V=0$. Thus, the short-time work components $\xi_{w}$ and $\xi_{f}$ increase the value of jobs and employed persons in the economy.

$$
\begin{gathered}
r W(\gamma)=\bar{\omega} \cdot h+\bar{\omega} \cdot \xi_{w}(\underline{h}-h)-\Omega(h)+\lambda[E(W)+F(\tilde{\gamma}) U-W(\gamma)] \\
r J(\gamma)=(1-\gamma) \cdot p(h)-\bar{\omega} \cdot \underline{h}+\bar{\omega} \cdot \xi_{f}(\underline{h}-h)+\lambda[E(J)-J(\gamma)]
\end{gathered}
$$

35

equicis

Notably, as the generosity of the instruments $\xi_{f}$ and $\Xi$ increases, the firing threshold increases $\left[\tilde{\gamma}_{i} \geq 0 \quad \forall \quad i=\xi_{f}, \Xi\right]$. Figure 1 gives a visual representation of the right shift of the firing threshold.

$$
\tilde{\gamma}=1-\frac{\bar{\omega}}{p(h)}\left(\underline{h}-\xi_{f} \Xi\right)+\frac{\lambda}{r+\lambda} \int_{\underline{\gamma}}^{\tilde{\gamma}}(\tilde{\gamma}-x) d F(x)
$$

An increase of the firing threshold decreases the unemployment effect following a natural disaster, which is evident from the evolution of unemployed individuals $\dot{u}=\lambda F(\tilde{\gamma}) \cdot(1-u)-\lambda_{w} \cdot u$, with $\lambda_{w}$ standing for the rate of match creation and $F(\tilde{\gamma})$ for the rate of match destruction. As $\tilde{\gamma}$ increases, $F(\tilde{\gamma})$ decreases, hence reducing the number of individuals entering unemployment. 
Figure 1: Firing threshold and short-time work

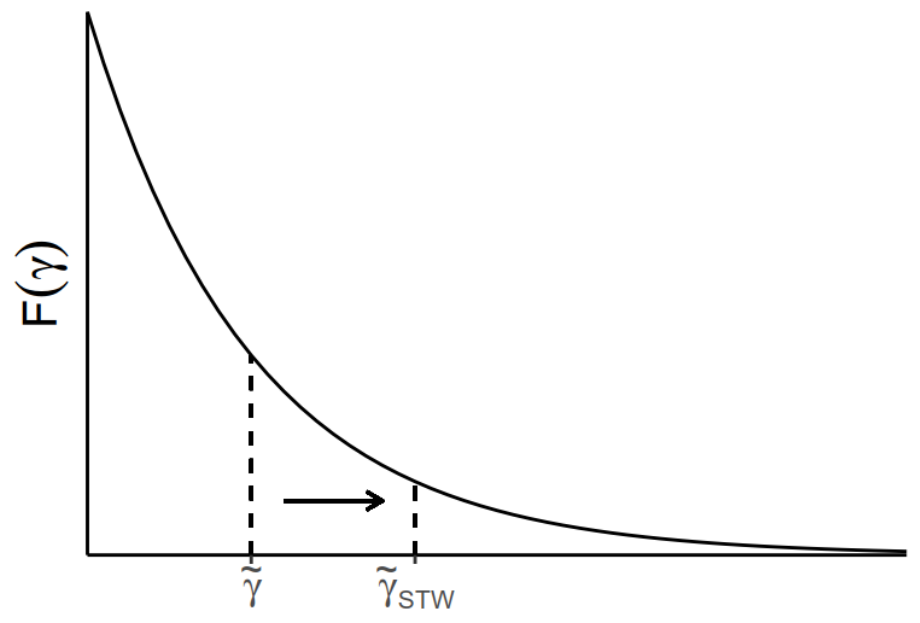

Notes: This figure shows the distribution of natural disaster shock intensities and how the firing threshold shifts to the right due to short-time work.

\footnotetext{
${ }^{9}$ The most affected river basins were the Danube, Elbe, Rhine, Wesser, Inn, Morava, Vltava, Ohre, Odra, Berounka, and their tributaries.

${ }^{10}$ Many of these regions declared a state of emergency, among them, eight states in Germany and six provinces in the Czech Republic. Further countries with minor damage include Croatia, Serbia, Romania, and Bulgaria.
} 
Salzburg (10\%) in Austria (European Commission, 2018); and Central Bohemia (27\%), Prague (25\%), Ústí nad Labem (23\%), and South Bohemia (13\%) in the Czech Republic (Czech Hydrometeorological Institute, 2014). Given the size of the losses, all of the aforementioned countries, except Hungary, received support from the European Union Solidarity Fund (EUSF) (European Commission, 2015). In Germany, the government launched flood-relief funds for around $€ 8$ billion, and the insurance industry covered around $€ 1.65$ billion (Thieken et al., 2016).

The flood caused infrastructure damages, including the transport, telecommunication, water, electricity, and gas networks. In Germany, reports reveal 250,000 hectares of flooded agricultural land and production disruptions in several prominent firms, including Porsche (Leipzig), Volkswagen (Zwickau), and Südzucker (Zeitz) (Khazai et al., 2013). Thieken et al. (2016) report that more than 32,000 residential buildings suffered damage and that around $19 \%$ of the direct losses corresponded to companies in the industrial and commercial sectors. The Czech Republic had 48,000 hectares of flooded agricultural land, 7,000 affected residential buildings, and about $16 \%$ of the direct costs accruing to businesses (Czech Hydrometeorological Institute, 2014). In Austria, 22,000 hectares of agricultural land remained underwater and over 300 firms were directly affected, while in Hungary, reports indicate 2,500 hectares of flooded farmland (European Commission, 2015).

\subsection{Short-time work programs}

Short-time work programs are employment subsidy mechanisms designed to prevent involuntary dismissals during periods of temporary business-downturn. Short-time working allowances are the corresponding transfers received by firms and paid to employees who benefit from temporary income support. Companies also benefit from the programs, as they retain core employees, avoid dismissal costs, and regain production levels without delay once the crisis is over. From a macro perspective, short-time work can slow the spiral of declining unemployment, wage deflation, and demand. Additionally, the psychological effect of being under the program rather than unemployed has a more substantial impact in supporting domestic demand than unemployment benefits (Crimmann et al., 2010). 
However, like other subsidies, short-time work schemes are subject to several problems that reduce their cost-effectiveness (Hijzen and Venn, 2011). The two most prominent are dead-weight losses and displacement costs. Dead-weight losses occur when benefiting employees would anyway be regular-time employed in the absence of short-time work. Displacement costs happen when the allowances preserve jobs that would have been destroyed in the absence of the subsidy, hence locking workers into low-productivity job matches. The consequences of the latter include the potential of preventing creative destruction processes (Crespo Cuaresma et al., 2008; Leiter et al., 2009) and impeding companies with strong growth potential to hire locked-in workers. These problems become more dramatic when crises last for a long time (Brenke et al., 2013).

Short-time work programs vary depending on generosity, work-sharing, eligibility, and conditionality requirements (Hijzen and Venn, 2011). These program design features can account for differences in participation rates across different countries (Boeri and Bruecker, 2011; Cahuc and Carcillo, 2011). Generosity refers to the cost of implementation, such as the share covered by firms, worker's perceived income, and the maximum duration of the program. Concerning company requirements to receive allowances, these include setting up the distribution of hour reductions among workers, providing evidence of temporary business downturns, or training obligations. Amendments to the regulatory framework, for instance, by making conditions more attractive or speeding up implementation, aim at increasing participation rates during periods of economic downturn. However, amendments imply a trade-off between takeup and cost-effectiveness, which in periods of crisis usually shifts toward maximizing participation (Hijzen and Venn, 2011). The shift occurs because dead-weight and displacement costs are less significant during economic downturns (Boeri and Bruecker, 2011). 


\footnotetext{
${ }^{11}$ The German Social Security Code SGB III, the Austrian Labor Market Services Act (§37b), and the Slovak Employment Services Act $(\S 50 \mathrm{k})$ contain additional details on the programs.

${ }^{12}$ Hungary implemented three different programs during the financial crisis, the two nationallyfinanced schemes finished in 2009 and an ESF-financed project completed in early 2010 (OECD, 2010). There was no evidence of any active post-recession short-time work scheme in the country.
} 
Table 1: Differences between short-time work programs in 2013

\begin{tabular}{lccccc}
\hline & Austria & Germany & Czechia & Hungary & Slovakia \\
& & & & & \\
\hline Permissible reductions & $10 \%-90 \%$ & $10 \%-100 \%$ & $20 \%-60 \%$ & - & $6 \%-20 \%$ \\
$\begin{array}{l}\text { Maximum duration } \\
\text { (months) }\end{array}$ & 24 & 24 & 12 & - & 3 \\
Replacement rate & $55 \%$ & $60 \%$ & $60 \%$ & - & $60 \%$ \\
Compensation rate & $55 \%$ & $60 \%$ & N/D & - & $30 \%$ \\
Compensation limit & $15 \%$ & $10 \%$ & $25 \%$ & - & $\checkmark$ \\
Cost to employer & & & $\checkmark$ & - & $\checkmark$ \\
$\begin{array}{l}\text { Initial job retention } \\
\text { (paid by employer) }\end{array}$ & $\checkmark$ & $\checkmark$ & & & $\checkmark$ \\
Program before 2008 & $\checkmark$ & $\checkmark$ & $\checkmark$ & - & $\checkmark$ \\
Program in 2013 & $\checkmark$ & $\checkmark$ & & - & \\
Flood amendments & & & & \\
\hline
\end{tabular}

Notes: This table compares program characteristics in different affected nations in 2013. Permissible reductions refer to the minimum and maximum reductions in weekly working hours. The maximum duration refers to the maximum number of months that an employee can receive the subsidy. The cost to the emplover is the percentage of the wage covered by firms for hours not worked (we borrow 2008 values from Hijzen and Venn (2011)). Evidence refers to the requirement of showing evidence of a business downturn. Flood amendments refer to the existence of any amendment facilitating participation during the 2013 floods.

\footnotetext{
${ }^{13}$ For a $100 \%$ loss of working time, the employee receives the same income as with unemployment benefits.

${ }^{14}$ These additional costs represented about $46 \%-59 \%$ of usual labor costs for each working hour lost in 2008 (Brenke et al., 2013).

${ }^{15} \mathrm{~A}$ company is indirectly affected when it limits production because the supplying companies cannot deliver due to flooding.
} 
ing the inter-war period of 1918-1939 (Suschitz, 2010). In 2013, employers whose activity was affected by temporary non-seasonal economic difficulties were eligible as long as they applied for assistance three weeks before the start of the program. The regular program's duration was between six and twenty-four months, requiring the loss of work to be between ten and ninety percent of the regular weekly working hours. Depending on the net remuneration level and irrespective of the number of working hours and associated loss, employees receive about ninety percent of their monthly salary. This program also saw considerable participation rates during previous disasters, such as the 2002 floods (Bock-Schappelwein et al., 2011). Furthermore, in the event of natural disasters, individual companies can bypass the requirement of having a collective agreement. Additionally, Austria employed several mechanisms to encourage participation during the floods. Through a public announcement, the authorities assured that the process was going to be handled "quickly and easily," as opposed to regular conventions (Niederösterreichische Nachrichten, 2013). The Labor Market Service in Tirol even launched a unique disaster-specific project under the title "Flood Disaster June 2013" (Tiroler Tageszeitung, 2013).

The Czech Republic implemented the program "Educate Yourself for Stability" (Vzdělávejte se pro stabilitu) between September 2012 and August 2015 (MLSACZ, 2012). The program received a total of CZK 400 million (around $€ 16$ million in 2013) ( $85 \%$ ESF and $15 \%$ national) to enable employers to obtain a financial contribution for implementing professional development programs during periods of economic downturn, including support to the wage costs of trained employees. To be eligible, companies needed to show a decrease of more than twenty percent in the volume of sales per employee in three calendar months before applying compared with the equivalent period of the previous year. Additionally, they must show that they could not allocate work for more than twenty percent of the weekly working hours (up to a maximum of sixty percent). Besides this, they must provide evidence that, at their own expense, they retained jobs for at least one month before the application. Note that employers must pay a wage compensation of at least sixty percent of average earnings to affected employees throughout the whole downturn period. The government subsidy supports this wage compensation. The monthly allowance covered up to CZK 31,000 (around 
$€ 1200$ in 2013) of the wage compensation amount. The regular period of granting the support was six months (up to twelve months).

Slovakia implemented the program "Contribution to Support the Maintenance of Jobs" (Príspevok na podporu udržania pracovných miest) (UPSVR, 2012). This program has many similarities to the one in the Czech Republic. To be eligible, employers must give evidence of a transitional business downturn and pay a wage compensation of at least sixty percent of average earnings to affected employees throughout that period. However, stricter than in the Czech Republic, they must show that they retained jobs at their own expense for at least three months before the application. The monthly short-time work allowance was fifty percent of this wage compensation, up to fifty percent of the country's average wage in the previous year (Slovakia's average gross monthly wage was close to $€ 800$ in 2012). The loss of work had to be between six and twenty percent of the contractual weekly working hours. Employers could implement the program for sixty working days, as long as the contractual relationship started at least twelve months before the request.

Despite the existence of short-time work in Slovakia and the Czech Republic, we could not find any information indicating its use or any amendment facilitating participation during the floods. Besides the lack of crisis-specific modifications, their programs' restrictive characteristics suggest that these countries did not have suitable mechanisms to reduce the disaster's adverse effects on their labor market. These restrictive characteristics include budget constraints and low levels of generosity in Slovakia or the training obligation and the "loss in the last three months" requirement in the Czech Republic. Motivated by this, in Slovakia as of 2020, there is pressure to shift to the German short-time work model. However, government officials claim that the introduction of such a model would require extensive legislative changes that the government does not foresee (MLSAF, 2020). Moreover, because participation rates in the Czech Republic in 2013 were lower than expected, in 2014, the authorities made several amendments to the program's features (LOCZ, 2014).

Figure 2 presents yearly series for the average number of reports and the total number of workers under short-time work in Germany and Austria. Although Germany discloses monthly data on a periodical basis, which we use later in the paper, we plot 


\footnotetext{
${ }^{16}$ Unfortunately, we could not find quantitative information regarding short-time work participation for other countries.
} 
Figure 2: Short-time work participation in Austria and Germany (yearly values)

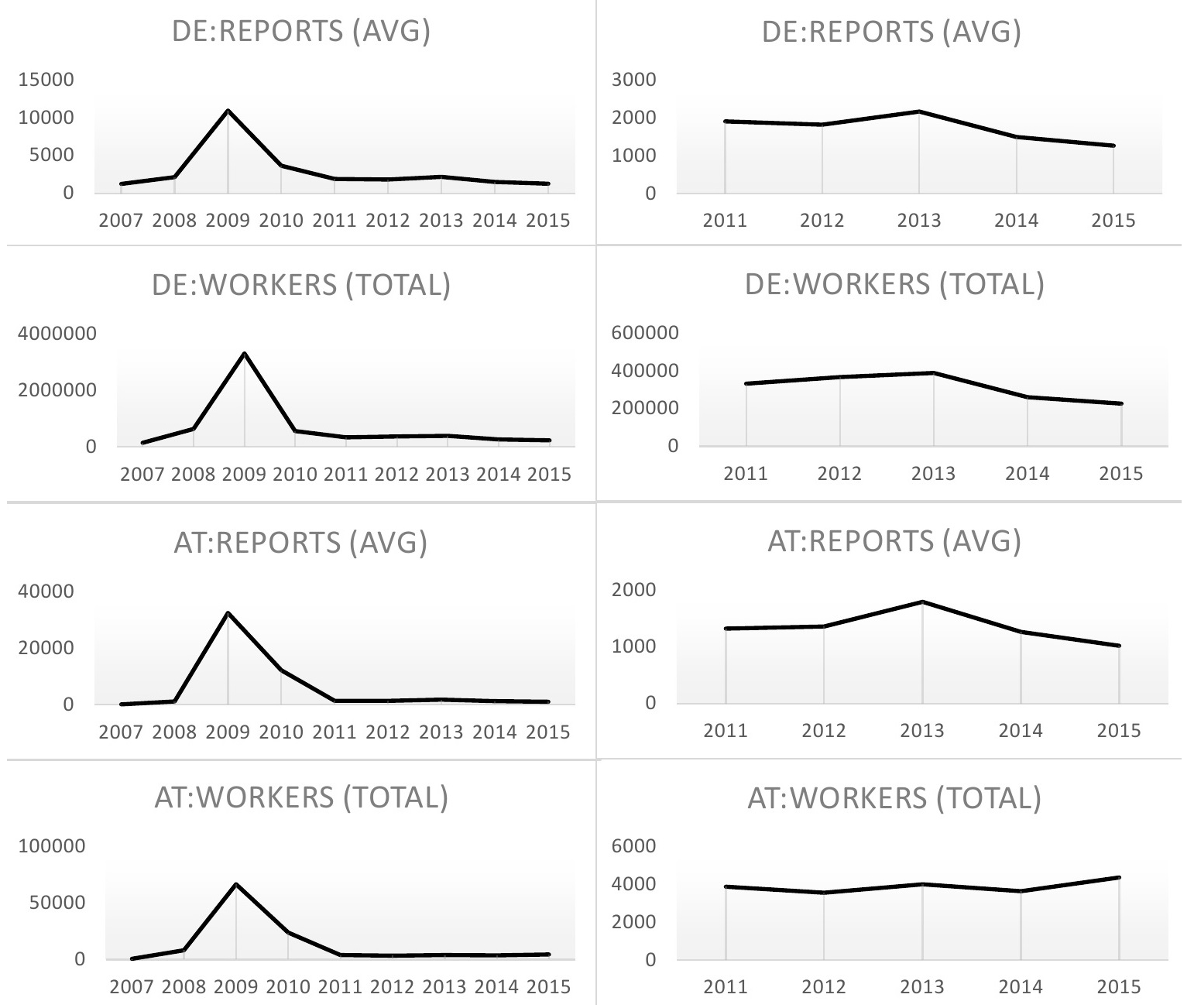

Notes: This figure shows short-time work participation in Austria and Germany. The left panel shows values from 2007 to 2015. To better visualize the shock in 2013, the right panel repeats the values from 2011 to 2015 . For Austria, reports are the annual average of the number of monthly funding cases and workers are the total number of employees who received funding in the year (Nagl et al., 2019). For Germany, reports are the annual average number of monthly reports (economic short-time work) and workers are the total number of employees that appear in the reports in that year (BA, 2020). Note that the magnitudes between the two countries are not directly comparable since each person is counted once in Austria, and not all reports receive funding in Germany.

Table 2 presents values on the two institutions for each of the five inundated countries. Regarding the strictness of employment protection, we see that although Austria, Germany, and Slovakia have similar index values, the Czech Republic has a much stricter employment protection legislation. It stands in contrast to Hungary, which has a much lower index value. These values suggest that in the Czech Republic, layoffs are more expensive relative to other countries. To substitute for this, companies will try to use time-flexibility measures and apply for wage-support assistance programs. Con- 
Table 2: Institutional interaction indicators in 2013

\begin{tabular}{lccccc}
\hline & Austria & Germany & Czechia & Hungary & Slovakia \\
\hline $\begin{array}{l}\text { Employment protection } \\
\text { strictness }\end{array}$ & 2.29 & 2.60 & 3.26 & 1.59 & 2.51 \\
$\begin{array}{l}\text { Generosity of unemploy- } \\
\text { ment benefits (percentage } \\
\text { of previous income) }\end{array}$ & $55 \%$ & $59 \%$ & $65 \%$ & $68 \%$ & $62 \%$ \\
\hline
\end{tabular}

Notes: This table reports values on the strictness of employment protection and the generosity of unemployment benefits for each inundated country. For the strictness of employment protection, we use the OECD index on individual and collective dismissals of regular contracts in 2013. For the generosity of unemployment benefits, we use the OECD net replacement rates in unemployment, which refer to the percentage of previous in-work income after two months of being unemployed in 2013.

cerning the generosity of unemployment, we see that while Austria and Germany have slightly lower values than the rest of the countries, Hungary has the most generous unemployment benefits. This means that employees in Hungary are, from an income perspective, better off going into unemployment than employees in other countries. Compared to short-time work replacement rates, we see that, while most counties have very similar values, the replacement rate of unemployment in the Czech Republic (Slovakia) is higher than that of short-time work by five (two) points. From an income perspective, employees might again prefer unemployment to short-time work. Altogether, it is possible to say the institutional setting in Hungary facilities labor adjustments via the extensive margin by combining lenient employment protection with high unemployment benefits. Although unemployment benefits are also high in the Czech republic, employment protection makes short-run employment adjustments somewhat prohibitive.

\section{Data and overview}

Conforming to the floods' duration and different severity levels by region, we use monthly data at the county level for the analysis. ${ }^{17}$ For all variables, we work exclusively with information for years 2011 to 2015, which corresponds to the most

\footnotetext{
${ }^{17}$ To homogenize counties across nations, we work at the NUTS (Nomenclature of Territorial Units for Statistics) 3 level.
} 


\footnotetext{
${ }^{18}$ We only use data on economic short-time work since it is the only category covering unexpected events including natural disasters.

${ }^{19}$ The Federal Employment Agency calculates the latter based on the difference between target and actual remunerations.

${ }^{20}$ Given that the Hungarian Central Statistical Office only discloses quarterly unemployment at the county level, we impute missing monthly values by using monthly national unemployment rates and quarterly regional shares of employment.

${ }^{21}$ Given that the algorithm generates several pixel edge errors along the coastline due to the use of a static reference water layer, we exclude inundations along the coast.

${ }^{22}$ Inundation areas per region follow a very skewed distribution, with a mean (median) value of 4.87 (0.86) square kilometers and a standard deviation of 14.41.
} 
Figure 3: The 2013 Central European floods by county and flood extent

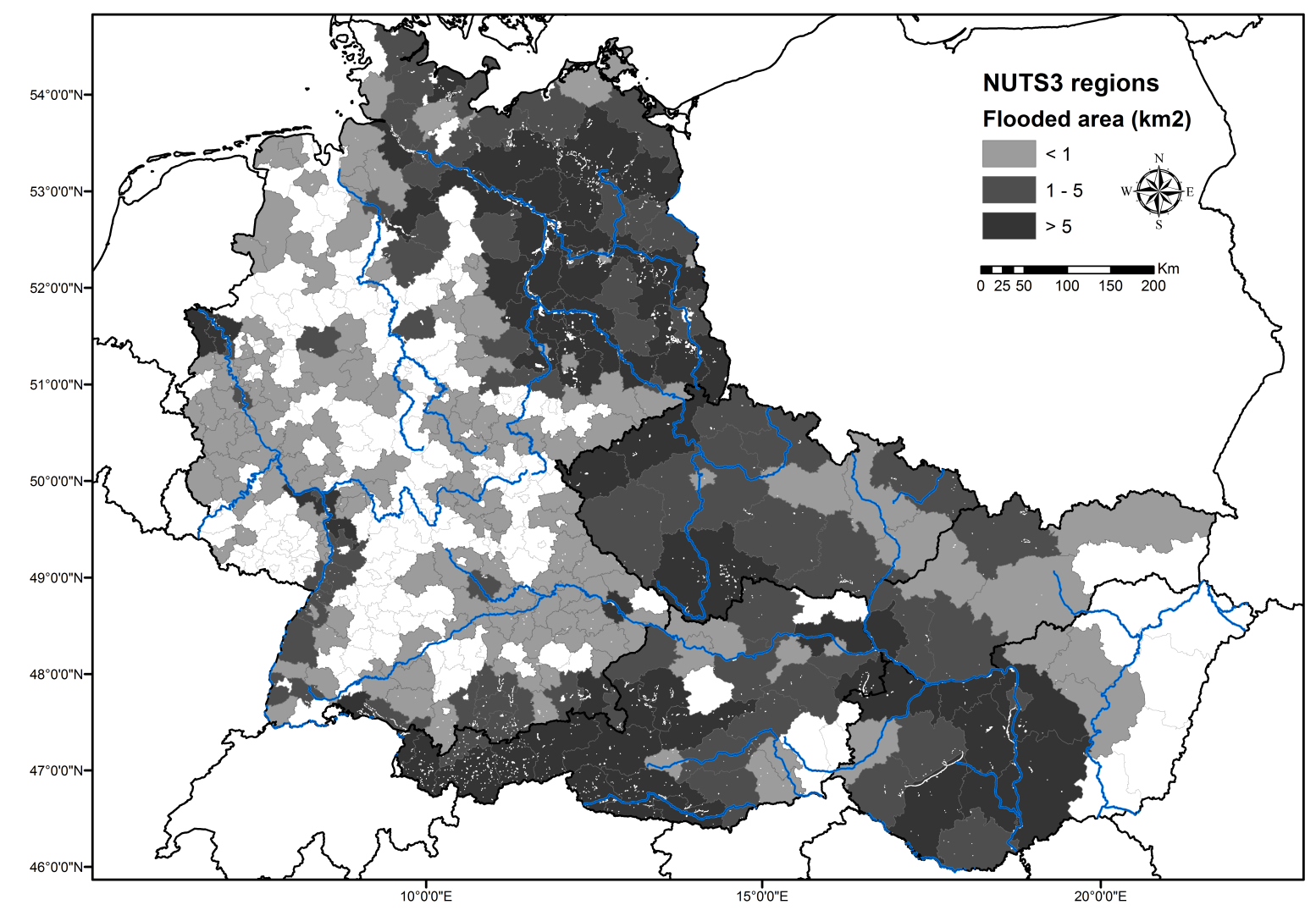

Geo-source: Policelli et al. (2017)

Notes: This map shows flood-affected counties (NUTS 3 regions) in the five affected nations according to three flood extent levels. To calculate flooded areas in $\mathrm{km}^{2}$ for each county, we sum up all inundations (in white) within each county. The main river network is in blue. 
Table 3: Flooded regions by flood extent and country

\begin{tabular}{lcccc}
\hline & $\begin{array}{c}\text { Number of affected } \\
\text { counties }\end{array}$ & $\begin{array}{c}\text { \% of all counties } \\
\text { in the country }\end{array}$ & $\begin{array}{c}\text { Total flooded } \\
\text { area }\left(\mathrm{km}^{2}\right)\end{array}$ & $\begin{array}{c}\text { \% of total area of } \\
\text { affected counties }\end{array}$ \\
\cline { 2 - 5 } Counties with reported high-water levels \\
Germany & 227 & 56.61 & 1059 & 0.42 \\
Austria & 30 & 85.71 & 155 & 0.21 \\
Czechia & 14 & 100 & 44 & 0.06 \\
Hungary & 15 & 75.00 & 148 & 0.23 \\
Slovakia & 7 & 87.50 & 19 & 0.05 \\
\hline Total & 293 & 61.30 & 1426 & 0.28 \\
\hline
\end{tabular}

Notes: For each flood-affected nation, this table presents the number and percentage of affected counties and corresponding flooded area in $\mathrm{km}^{2}$.

Figure 4 plots the temporal variation of the three variables measuring short-time work in Germany. From the left panel, we see that, at the monthly level, short-time work is higher during the first months of the year and lower in the summer months and December. Concerning yearly behavior, short-time work decreases throughout the sample period, with its highest value in 2011 and its lowest in 2015, in line with the yearly country-level figures presented above. This long-term behavior comes from the German busyness cycle and its recovery after the 2008 financial crisis. To have a better look at the behavior of the variables during the flood, Table 4 presents the May-to-June growth rates in 2012, 2013, and 2014. The first row in each panel shows the value for all counties in the country, the next only for flooded counties, and the third for Stendal, the most flooded county. While, in line with the average monthly variation, changes in 2012 and 2014 are generally negative and always small; in 2013, they are positive and larger in magnitude. As expected, the effects become larger when we only include flooded counties, and they become enormous for Stendal, with growth values over $4,000 \%$ in the number of FTEs. ${ }^{23}$

Finally, Figure 5 presents monthly and yearly variation in regional unemployment rates across affected Central European countries. On average, regional unemployment rates are higher in Slovakia and lower for Austria and Germany. All nations exhibit a u-shaped monthly behavior with valleys in the summer and peaks during the winter, notably Austria and the Czech Republic. Concerning the long-term behavior, we can see a negative trend in Germany, Hungary, and the Czech Republic. In Slovakia, unemployment increases until 2013 and drops sharply thereafter, while in Austria, we

\footnotetext{
${ }^{23}$ The results keep increasing in size as we increase the flood threshold to consider a county as inundated.
} 
Figure 4: Temporal variation in regional short-time work in Germany
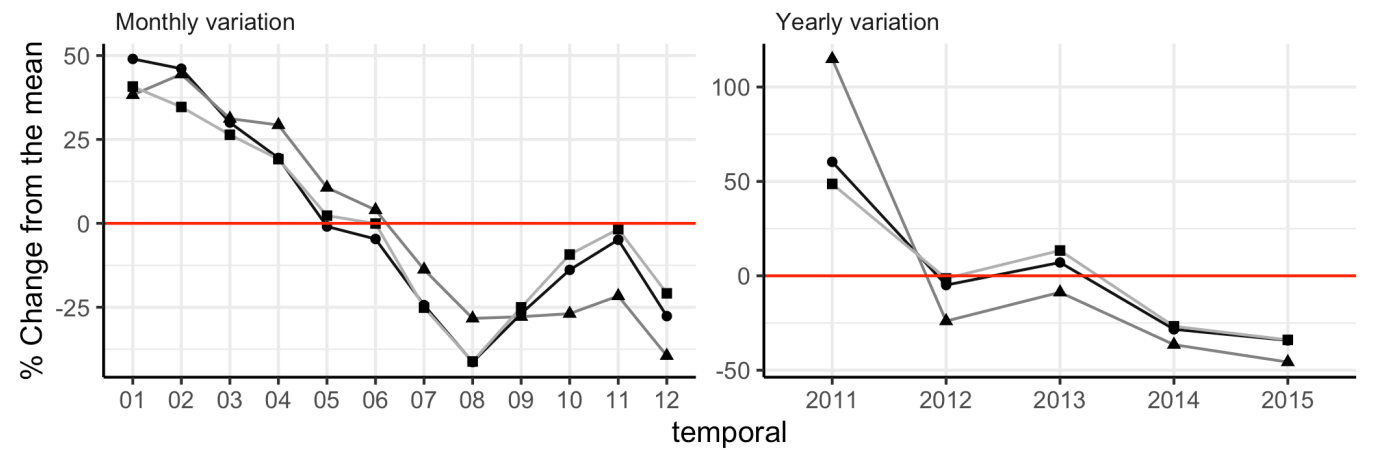

Notes: The figure shows the temporal variation in average regional short-time work participation for each month of the year (left panel) and each year of the sample period (right panel). The y-axis gives the percentage deviation from the overall average. For example, a value of zero means that for that month (year), short-time work is the same as the average over all months (years).

Table 4: May-to-June regional short-time work participation growth rates in Germany

\begin{tabular}{lccc}
\hline & \multicolumn{3}{c}{ May-to-June growth } \\
\cline { 2 - 4 } & 2012 & 2013 \\
\hline & \multicolumn{3}{c}{ Short-time companies } \\
\cline { 2 - 4 } All counties & $-7.76 \%$ & $24.25 \%$ & $-11.96 \%$ \\
Flooded counties & $-5.49 \%$ & $41.52 \%$ & $-13.07 \%$ \\
Stendal & $-14.29 \%$ & $2100.00 \%$ & $0.00 \%$ \\
\cline { 2 - 4 } All counties & \multicolumn{3}{c}{ Short-time employees } \\
Flooded counties & $-10.26 \%$ & $16.73 \%$ & $-7.76 \%$ \\
Stendal & $-6.77 \%$ & $21.38 \%$ & $-6.70 \%$ \\
& $3.85 \%$ & $1844.83 \%$ & $0.00 \%$ \\
All counties & \multicolumn{3}{c}{ FTEs } \\
Flooded counties & $-9.76 \%$ & $28.36 \%$ & $-19.69 \%$ \\
Stendal & $-5.52 \%$ & $35.75 \%$ & $-8.35 \%$ \\
\hline
\end{tabular}

Notes: This table presents May-to-June growth rates of short-time companies (upper panel), employees (middle panel), and FTEs (lower panel) in 2012, 2013, and 2014, for different groups of counties. Except for the district of Stendal, values are regional averages over all counties in a given group.

can see a stable increase between 2011 and 2015. 
Figure 5: Temporal variation in regional unemployment

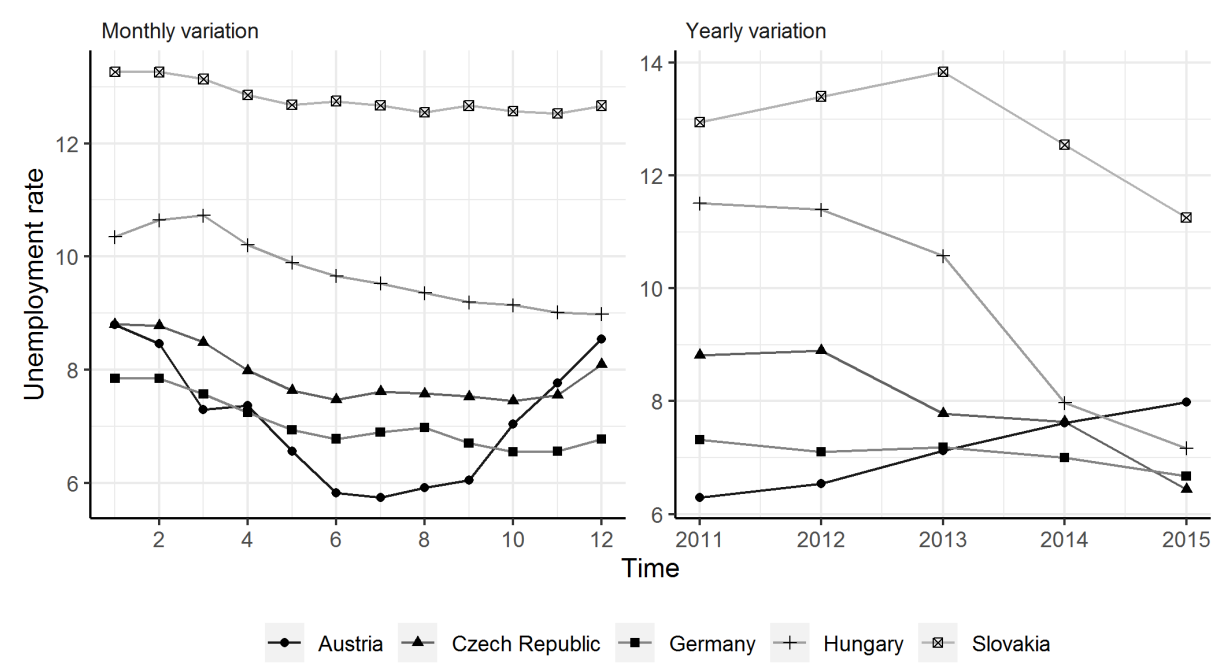

Notes: This figure shows the temporal variation in average regional unemployment rates for the Central European countries affected by the 2013 European floods. The left panel shows the month to month averages and the right panel the yearly means.

\section{Empirical strategy}

To determine if short-time work programs are effective in avoiding unemployment after a natural disaster, we first provide empirical evidence on the use of short-time work in Germany and the stability of employment in Germany and Austria during the floods. If the floods have an impact, we would expect to see a significant increase in all short-time work variables. Although data limitations prevent us from conducting this exercise for other nations, we expect these to have lower participation rates considering that the restrictive characteristics of the programs limit participation (Boeri and Bruecker, 2011; Cahuc and Carcillo, 2011). Further, given the robust characteristics of programs in Germany and Austria, we expect to find little to no monthly unemployment effects.

Could Germany and Austria have experienced no unemployment changes even in the absence of a robust short-time work program? To see if short-time work is related to previous labor market outcomes, we exploit the variation in short-time work program characteristics in other flooded nations and flood extent intensities. Although we would ideally compare flooded regions in Germany and Austria with other same countries' flooded regions without (sufficient) access to short-time work, the countrywide coverage of the programs does not allow us to construct such a counterfactual. 


\footnotetext{
${ }^{24}$ For instance, if May and June are months with high levels of unemployment, failing to control for the month effect would increase the coefficients of a simple regression discontinuity design.

${ }^{25}$ Gelman and Imbens (2019) provide evidence on the better performance of local linear fits versus higher-order polynomials of the running variable in regression discontinuity designs.

${ }^{26}$ For all regressions, we use the $\mathrm{R}$ package 'rdrobust' (Calonico et al., 2015).

${ }^{27}$ Studies using the same first log-difference growth specification include Felbermayr and Gröschl (2014) or Loayza et al. (2012).
} 


$$
\Delta \ln y_{c t}^{i}=\rho_{i} \ln y_{c t-1}^{i}+\omega_{t}+v_{t}+\gamma_{c}+\mu_{c t}^{i}
$$

Equation 6 specifies the functional form of the second stage. $\mu_{s t}^{i}$ are the residuals

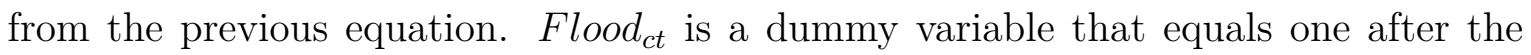
flood and zero otherwise. $\beta_{i}$ is the point estimate of interest as it measures the impact of the flood at the discontinuity. $x_{c t}$ is a running variable measuring the temporal distance to the discontinuity date. $f\left(F_{l o o d} \times x_{c t}\right)$ is a linear trend before and after the discontinuity, and $\epsilon_{c t}$ is an idiosyncratic error term. Because the floods began in May 2013, and companies were not able to receive benefits until June, we set the discontinuity for the short-time work variables to June and for the unemployment rates to May. Finally, we cluster standard errors at the month $\times$ county level.

$$
\mu_{c t}^{i}=\beta_{i} \text { Flood }_{c t}+f\left(\text { Flood }_{c t} \cdot x_{c t}\right)+\epsilon_{c t}^{i}
$$

We report results using robust-bias-corrected (RBC) confidence intervals. RBC differs from conventional OLS confidence intervals in that they take into consideration the bias stemming from the non-parametric approximation of the local polynomial in the determination of point estimates and standard errors at the discontinuity. According to Cattaneo et al. (2019), these estimates are theoretically valid, enjoy excellent optimality properties, and perform well in empirical applications. Additionally, we report observations to the left and right of the discontinuity, the bandwidth around the threshold, and the polynomials for both the estimate fit and its bias correction. The bandwidth around the discontinuity comes from the plug-in rules based on mean square error expansions described by Calonico et al. (2015).

The basis for identification is the idea that the floods are the only reason behind changes in our dependent variables at the date of the discontinuity. The only threat to identification is that conditional on year, month, and county fixed effects, there might still be uncontrolled and discontinuous time effects on the month of the floods. However, we do not find evidence of other relevant shocks occurring in the same counties and dates of the 2013 events. To test the robustness of the results, we also conduct placebo tests that randomize the discontinuity across space and time. 
Figure 6: Discontinuity of short-time work residuals in Germany
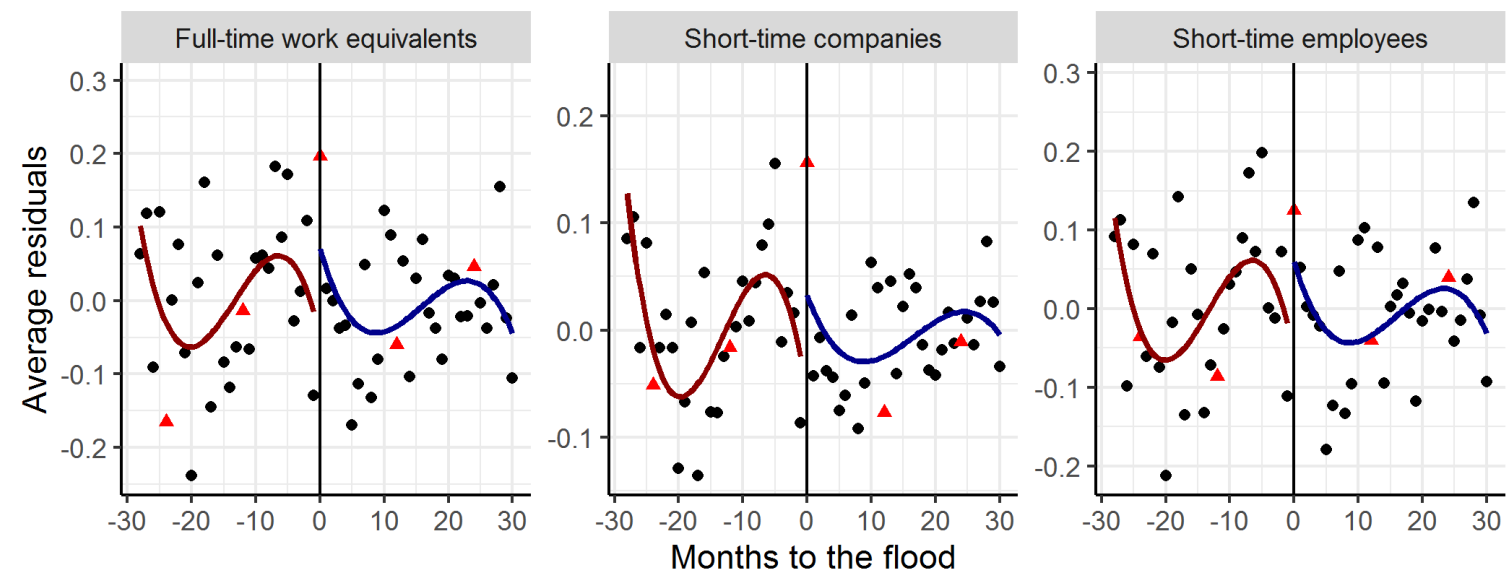

Notes: This figure contains the graphical representation of the discontinuity at $t=0$ (June 2013) of the average residuals from the first difference of short-time-work variables (Equation 5). The red marks correspond to June 2011, 2012, 2013, 2014, and 2015. The global polynomial is of order 3 and uniform kernel.

\subsection{Unemployment in flooded nations}

611 Figure 7 shows the discontinuity in the unemployment residuals in flooded counties in

${ }_{612}$ Germany and Austria. Unlike the previous figures, there is a small negative spike for 
Table 5: Regression discontinuity results for short-time work participation in Germany

\begin{tabular}{lccc}
\hline & \multicolumn{3}{c}{ Discontinuity: 2013 European Floods } \\
\cline { 2 - 4 } & $\Delta \ln$ Companies & $\Delta \ln$ Employees & $\Delta \ln$ FTEs \\
\hline Robust Bias Corrected (RBC) & $0.29^{* * *}$ & $0.25^{* *}$ & $0.33^{* * *}$ \\
& $(0.05)$ & $(0.08)$ & $(0.07)$ \\
\hline Obs. to the Left & 669 & 894 & 894 \\
Obs. to the Right & 881 & 1101 & 1101 \\
Conventional Est. Bandwidth & 3.85 & 4.74 & 4.41 \\
Bias-Corrected Est. Bandwidth & 10.77 & 8.64 & 9.75 \\
\hline
\end{tabular}

Notes: ${ }^{* * *} p<0.001,{ }^{* *} p<0.01,{ }^{*} p<0.05$; this table contains the results from the augmented local linear regression discontinuity design on the average number of short-time companies, short-time workers, and full-time work equivalents in the German counties affected by the 2013 European floods. The discontinuity month is June 2013. Standard errors are clustered at the county $\times$ month level. The order of the local-polynomial to construct the estimator (bias-correction) is 1 (2). The kernel function is triangular.

\begin{tabular}{lcc}
\hline & \multicolumn{2}{c}{ Discontinuity: 2013 European Floods } \\
\cline { 2 - 3 } & Austria & Germany \\
& $\Delta \ln$ Unemployment & $\Delta \ln$ Unemployment \\
\hline Robust Bias Corrected (RBC) & -0.09 & $-0.01^{* *}$ \\
& $(0.09)$ & $(0.00)$ \\
\hline Obs. to the Left & 150 & 2043 \\
Obs. to the Right & 180 & 2270 \\
Conventional Est. Bandwidth & 5.62 & 9.32 \\
Bias-Corrected Est. Bandwidth & 9.77 & 15.03 \\
\hline
\end{tabular}

Notes: ${ }^{* * *} p<0.001,{ }^{* *} p<0.01,{ }^{*} p<0.05$. This table contains the results from the augmented local linear regression discontinuity design on the rates of unemployment for Austria and Germany. The discontinuity month is May 2013 Standard errors are clustered at the county $\times$ month level. The order of the local-polynomial to construct the estimator (bias-correction) is $1(2)$. The kernel function is triangular.

\footnotetext{
${ }^{28} \mathrm{As}$ noted in the introduction and in line with this finding. Germany's unemployment rate also declined during the 2008 financial crisis (Messenger and Ghosheh, 2013).
} 
Figure 7: Discontinuity of unemployment residuals in Austria and Germany

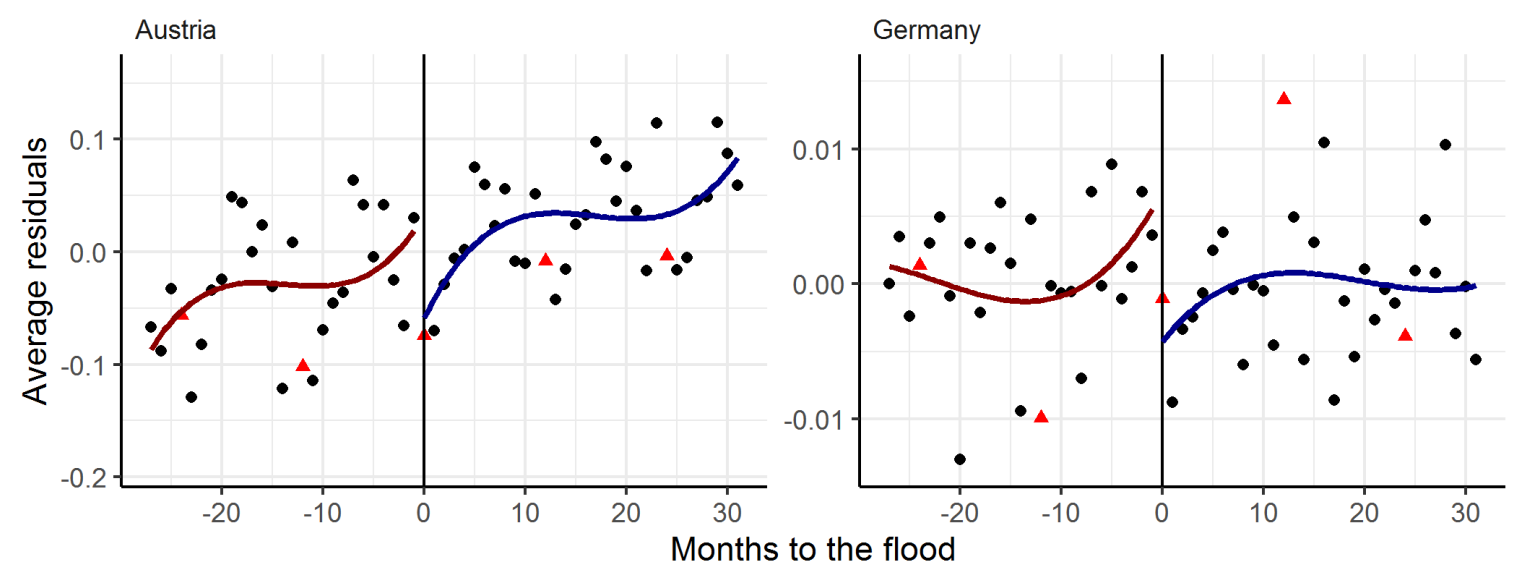

Notes: This figure contains the graphical representation of the discontinuity at $t=0$ (May 2013) of the average residuals from the first difference of unemployment (Equation 5). The red marks correspond to June 2011, 2012, 2013, 2014, and 2015, except for Austria, for which we do not have data for 2011. The global polynomial is of order 3 and uniform kernel.

Figure 8 shows the discontinuity in the unemployment residuals in flooded counties of the other affected nations. In all cases, we can visually distinguish positive spikes at the discontinuity in the month of the flood, albeit smaller in magnitude compared to short-time participation variables. Table 7 shows the point estimates of the ARDiT design. All three countries show a significant increment after the floods. For the Czech Republic, Hungary, and Slovakia, the estimate indicates that the flood increased unemployment by $7 \%, 9 \%$, and $6 \%$, respectively. These results are insightful in that the unemployment rate of nations with less robust and generous short-time work schemes increases in the aftermath of the flood. That the most substantial effect is for Hungary is not surprising, given the absence of any short-time work program in this country.

\subsection{Different flood extent intensities}

Table 8 extends the previous results for different flood extent intensities: counties with more than one and more than five square kilometers of flooded land. From the first three columns, we see that all short-time work estimates grow significantly with the size of the affectation. For the number of short-time companies, employees, and FTEs, moving from all flooded counties to counties with more than five square kilometers of 
Figure 8: Discontinuity of unemployment residuals in other flooded nations
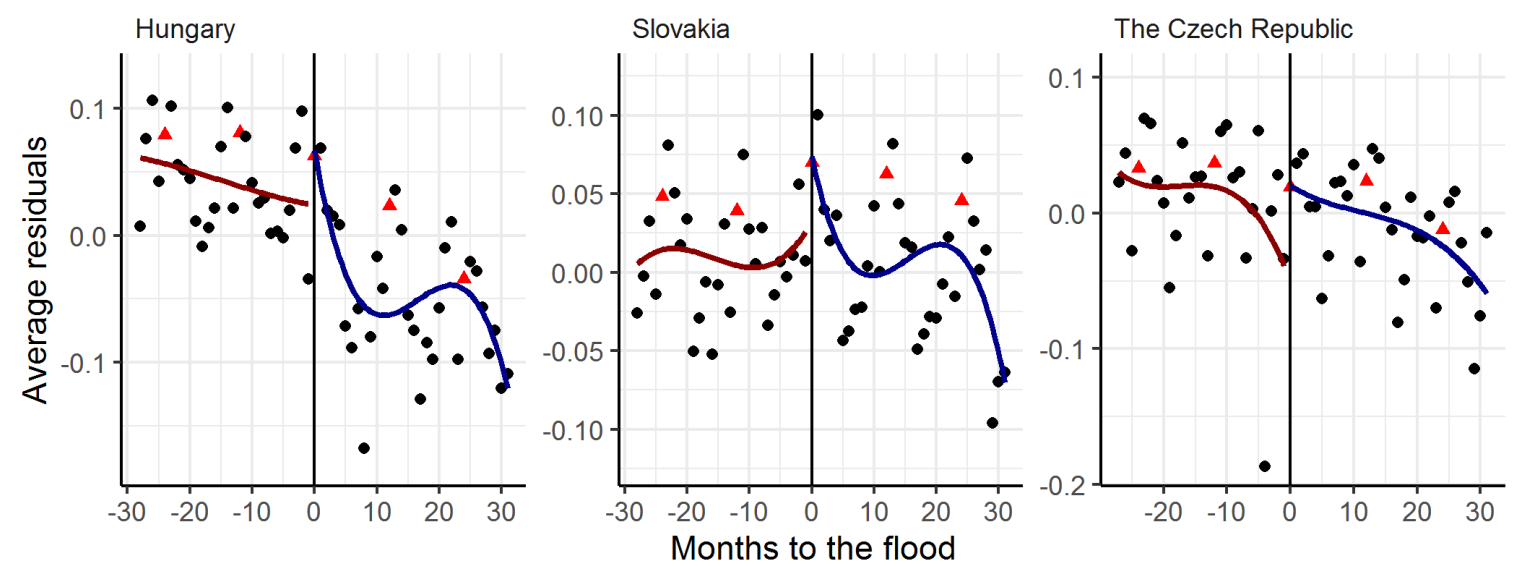

Notes: This figure contains the graphical representation of the discontinuity at $t=0$ (May 2013) of the average residuals from the first difference of unemployment (Equation 5). The red marks correspond to June 2011, 2012, 2013, 2014, and 2015. The global polynomial is of order 3 and uniform kernel.

Table 7: Regression discontinuity results for unemployment in other flooded nations

Discontinuity: 2013 European Floods (May 2013)

\begin{tabular}{lccc} 
& The Czech Republic & Hungary & Slovakia \\
& $\Delta \ln$ Unemployment & $\Delta \ln$ Unemployment & $\Delta \ln$ Unemployment \\
\hline Robust Bias Corrected (RBC) & $0.07^{* * *}$ & $0.09^{*}$ & $0.06^{* * *}$ \\
& $(0.02)$ & $(0.04)$ & $(0.02)$ \\
\hline Obs. to the Left & 42 & 75 & 42 \\
Obs. to the Right & 56 & 90 & 49 \\
Conventional Est. Bandwidth & 3.60 & 5.73 & 6.02 \\
Bias-Corrected Est. Bandwidth & 6.22 & 10.19 & 8.69 \\
\hline
\end{tabular}

Notes: ${ }^{* * *} p<0.001,{ }^{* *} p<0.01,{ }^{*} p<0.05$. This table contains the results from the augmented local linear regression discontinuity design on the rate of unemployment for the Czech Republic, Hungary, and Slovakia. The discontinuity month is May 2013. Standard errors are clustered at the county $\times$ month level. The order of the local-polynomial to construct the estimator (bias-correction) is 1 (2). The kernel function is triangular.

flooded land, increases point estimates by $46 \%, 51 \%$, and $43 \%$, respectively. Regarding unemployment, from columns four and five, we see that, while the coefficient does not change for Germany, it slightly (negatively) grows for Austria but lacks significance throughout the inundation intensities. The last three columns give the results for the other nations. In line with our expectations, we see that unemployment increases with 
Table 8: Regression discontinuity results for different flood extent intensities moving from all flooded counties to counties with more than five square kilometers of flooded land, the Czech Republic and Hungary undergo unemployment increases of $7 \%$ and $8 \%$, respectively. In Slovakia, unemployment increases by $3 \%$ at the one square kilometer threshold.

\begin{tabular}{|c|c|c|c|c|c|c|c|c|}
\hline & \multicolumn{8}{|c|}{ Discontinuity: 2013 European Floods } \\
\hline & \multicolumn{3}{|c|}{$\Delta \ln$} & \multicolumn{5}{|c|}{$\Delta \ln$ Unemployment } \\
\hline & Companies & Employ & sFFEs & Austria & Germany & Czechia & Hungary & Slovakia \\
\hline RBC (All) & $\begin{array}{c}0.29^{* * *} \\
(0.05)\end{array}$ & $\begin{array}{l}0.25^{* *} \\
(0.08)\end{array}$ & $\begin{array}{c}0.33^{* * *} \\
(0.07)\end{array}$ & $\begin{array}{l}-0.09 \\
(0.09)\end{array}$ & $\begin{array}{c}-0.01^{* *} \\
(0.00)\end{array}$ & $\begin{array}{c}0.07^{* * *} \\
(0.02)\end{array}$ & $\begin{array}{c}0.09^{*} \\
(0.04)\end{array}$ & $\begin{array}{c}0.06^{* * *} \\
(0.02)\end{array}$ \\
\hline $\operatorname{RBC}\left(1 \mathrm{~km}^{2}\right)$ & $\begin{array}{c}0.40^{* * *} \\
(0.08)\end{array}$ & $\begin{array}{c}0.39^{* *} \\
(0.13)\end{array}$ & $\begin{array}{c}0.46^{* * *} \\
(0.12)\end{array}$ & $\begin{array}{l}-0.13 \\
(0.10)\end{array}$ & $\begin{array}{c}-0.01^{* *} \\
(0.00)\end{array}$ & $\begin{array}{c}0.10^{* * *} \\
(0.02)\end{array}$ & $\begin{array}{c}0.11^{*} \\
(0.05)\end{array}$ & $\begin{array}{c}0.09^{* * *} \\
(0.03)\end{array}$ \\
\hline $\operatorname{RBC}\left(5 k m^{2}\right)$ & $\begin{array}{c}0.75^{* * *} \\
(0.15)\end{array}$ & $\begin{array}{c}0.76^{* * *} \\
(0.19)\end{array}$ & $\begin{array}{c}0.76^{* * *} \\
(0.17)\end{array}$ & $\begin{array}{c}-0.13 \\
(0.11)\end{array}$ & $\begin{array}{c}-0.01^{*} \\
(0.01)\end{array}$ & $\begin{array}{l}0.14^{*} \\
(0.07)\end{array}$ & $\begin{array}{c}0.17^{*} \\
(0.07)\end{array}$ & $\begin{array}{c}0.14 \\
(0.11)\end{array}$ \\
\hline
\end{tabular}

Notes: ${ }^{* * *} p<0.001,{ }^{* *} p<0.01,{ }^{*} p<0.05$; this table contains the results from the augmented local linear regression discontinuity design on short-time work and unemployment variables in counties affected by the 2013 European floods. Standard errors are clustered at the county $\times$ month level. RBC stands for robust-bias-corrected estimates. In parenthesis, the minimum flooded area required to include a county in the regression.

the size of the inundation. Considering only significant coefficients, we see that, when

.

\subsection{Robustness}

We test the robustness of our results by shifting the floods to Finland, Scotland, and the United Kingdom, countries that were utterly unaffected by the 2013 European floods. ${ }^{29,30}$ If the design is robust, we should not capture any impact at the discontinuity in these nation's unemployment rate. Table B.1 shows the estimation results. As expected, the point estimates are small and not significant for Finland and Scotland. Although the coefficient is significant in the UK-EWNI block, it is negative and small in magnitude.

\footnotetext{
${ }^{29}$ The estimates for the United Kingdom refer to England, Wales, and Northern Ireland.

${ }^{30}$ Monthly unemployment data for counties in Finland comes from the Employment Service Statistics of the Ministry of Economic Affairs and Employment (MEAE, 2020). Quarterly unemployment data for counties in the UK comes from the Annual Population Survey by the Office for National Statistics (ONS, 2020).
} 


\section{Conclusions}

Based on evidence indicating that employment falls in the immediate aftermath of a natural disaster and on studies highlighting the effectiveness of short-time work programs in retaining jobs during the 2008 financial crisis, in this paper, we investigate the efficacy of short-time work to stabilize employment during the 2013 European floods. The empirical strategy uses regression discontinuity designs and exploits differences in the institutional background of affected nations to understand the dampening ability of short-time work programs. The model uses the sharp discontinuity in the flooded month to compare the value of variables just before and after the event.

Better than during the 2008 financial crisis, our results show that the short-time work mechanism could completely stabilize employment in flood-affected regions, in line with the literature that this mechanism reaches its maximum efficiency during short-lived shocks. We find high participation rates in Germany's flood-stricken regions and no unemployment changes in countries with robust short-time work programs (Germany and Austria), while uncovering increments in nations with less robust mechanisms. Specifically, regional unemployment rates in flooded regions of the Czech Republic, Hungary, and Slovakia increase by $7 \%, 9 \%$, and 6\%, respectively. As we reduce the sample only to include regions with a larger flooded area, we find that Germany's short-time work participation increases further, with unemployment remaining unaffected in Germany and Austria, but further increasing in the other flooded countries. Although the effects might point to different labor market mechanisms in each of the countries, we contend that, given that the impact happens simultaneously in many countries, it can be attributed to weaknesses or the absence of programs.

In a globalized world threatened with uncertainties of uncountable types, a better understanding of labor market programs' effectiveness is essential for ensuring economic well-being. The findings in this work are of interest for countries considering the implementation or adaptation of similar policies to cope with disasters' consequences. However, this does not mean that the German and Austrian programs can have the same effects in other contexts. As also argued by Boeri and Bruecker (2011), the success of such a program hinges upon other labor market institutions and their 
interactions. Note also that, even if the short-time work mechanism was effective during the floods, we could not say anything about its cost-efficiency. It might be that, although the program could stabilize employment in flood-affected regions, the number of subsidized hours was inefficient. In the case of dead-weight losses, programs might include experience-rating components.

Further analyses, similar to those studying the 2008 financial crisis, could combine plant-level data with flood extent and land-use information, to study the determinants of the short-time work take-up decision at the firm and regional levels. Further opportunities include studying the behavior of additional labor market indicators, such as wages, or analyzing how the program affects the economy in the long run, for instance, by preventing creative destruction processes.

\section{Acknowledgments}

This work was possible thanks to two scholarships from the Graduate Center at DIW Berlin. We thank all the colleagues at the Energy, Transportation and Environment department at DIW Berlin for their useful comments, as well as Adam Lederer for proofreading the article.

\section{References}

Abraham, K. G. and Houseman, S. N. (1993). Does employment protection inhibit labor market flexibility? Lessons from Germany, France, and Belgium. Technical report, National Bureau of Economic Research. Retrieved from: https://www. nber.org/papers/w4390.pdf.

Anderson, M. L. (2014). Subways, strikes, and slowdowns: The impacts of public transit on traffic congestion. American Economic Review, 104(9):2763-96.

Arpaia, A., Curci, N., Meyermans, E., Peschner, J., and Pierini, F. (2010). Short time working arrangements as response to cyclical fluctuations. Technical report, European Commission. European economy occasional papers 
64. Retrieved from: https://ec.europa.eu/economy_finance/publications/ occasional_paper/2010/pdf/ocp64_en.pdf.

AuM (2020). Arbeitsmarktdaten und Medien Österreich. Data retrieved from: https://www.ams.at/arbeitsmarktdaten-und-medien/ arbeitsmarkt-daten-und-arbeitsmarkt-forschung/ berichte-und-auswertungen.

BA (2013). Hinweisblatt für Inhaber von Betrieben, die von Arbeitsausfällen auf Grund des Hochwassers betroffen sind [Information sheet for owners of companies affected by lost work due to the flood]. Technical report, Bundesagentur für Arbeit. Bundesagentur für Arbeit (BA). Retrieved from: https: //www.hwk-reutlingen.de/fileadmin/hwk/betriebsberatung_dokumente/ hochwasserhilfe2013/arbeitsagentur_merkblatt_kug2013_hochwasser.pdf.

BA (2014). Geschäftsbericht 2013: Zweiundsechzigster Geschäftsbericht der Bundesagentur für Arbeit (BA) [Annual report 2013: Sixty-second annual report of the Federal Employment Agency (BA)]. Technical report, Bundesagentur für Arbeit. Bundesagentur für Arbeit (BA). Retrieved from: https://www.arbeitsagentur. de/datei/geschaeftsbericht2013_ba015186.pdf.

BA (2020). Bundesagentur für Arbeit. Data retrieved from: https://statistik. arbeitsagentur.de/.

Balleer, A., Gehrke, B., Lechthaler, W., and Merkl, C. (2016). Does short-time work save jobs? A business cycle analysis. European Economic Review, 84:99-122.

Barone, G. and Mocetti, S. (2014). Natural disasters, growth and institutions: A tale of two earthquakes. Journal of Urban Economics, 84:52-66.

Belasen, A. R. and Polachek, S. W. (2008). How hurricanes affect wages and employment in local labor markets. American Economic Review, 98(2):49-53.

Bispinck, R. (2009). Tarifliche Regelungen zur befristeten Arbeitszeitverkürzung: Eine Untersuchung von Tarifverträgen in 26 Wirtschaftszweigen und Tarifbereichen [Collective bargaining regulations for temporary reductions in working hours: An ex- 
amination of collective bargaining agreements in 26 branches of industry and collective bargaining areas]. Technical report, Institute of Economic and Social Research (WSI). Retrieved from: https://www.boeckler.de/pdf/p_ta_elemente_ arbeitszeitverkuerzung_2009.pdf.

Bock-Schappelwein, J., Mahringer, H., and Rückert, E. (2011). Kurzarbeit in Deutschland und Österreich. Technical report, Arbeitsmarktservice Österreich. AMSWIFO-Report, Vienna. Retrieved from: http://www.forschungsnetzwerk.at/ downloadpub/ams_wifoKUA_Endbericht_2011.pdf.

Boeri, T. and Bruecker, H. (2011). Short-time work benefits revisited: Some lessons from the Great Recession. Economic Policy, 26(68):697-765.

Bogedan, C., Brehmer, W., and Herzog-Stein, A. (2009). Betriebliche Beschäftigungssicherung in der Krise: Eine Kurzauswertung der WSI-Betriebsrätebefragung 2009 [Job security in the crisis: A short evaluation of the WSI works council survey 2009]. Technical report, Institute of Economic and Social Research (WSI). Retrieved from: https://www.wsi.de/de/faust-detail.htm?sync_id=5776.

Bohachova, O., Boockmann, B., and Buch, C. M. (2011). Labor demand during the crisis: What happened in Germany? Technical report, Institute for Applied Economic Research at the University of Tübingen. Retrieved from: https://www. econstor.eu/bitstream/10419/56779/1/689529945.pdf.

Boysen-Hogrefe, J. and Groll, D. (2010). The German labour market miracle. National Institute Economic Review, 214(1):R38-R50.

Brenke, K., Rinne, U., and Zimmermann, K. F. (2013). Short-time work: The German answer to the Great Recession. International Labour Review, 152(2):287-305.

Brown, S. P. (2006). The effect of hurricane Katrina on employment and unemployment. Monthly Lab. Rev., 129:52.

Burda, M. and Hunt, J. (2011). What explains the German labor market miracle in the Great Recession? Brookings Papers on Economic Activity, 42:273-335. 
Burger, N. E., Kaffine, D. T., and Yu, B. (2014). Did California's hand-held cell phone ban reduce accidents? Transportation Research Part A: Policy and Practice, 66:162-172.

Cahuc, P. and Carcillo, S. (2011). Is short-time work a good method to keep unemployment down? Nordic Economic Policy Review, 1(1):133-165.

Calonico, S., Cattaneo, M. D., and Titiunik, R. (2015). rdrobust: An R package for robust nonparametric inference in regression-discontinuity designs. $R$ Journal, $7(1): 38-51$.

Cattaneo, M. D., Idrobo, N., and Titiunik, R. (2019). A Practical Introduction to Regression Discontinuity Designs: Foundations. Cambridge University Press.

Cavallo, E., Galiani, S., Noy, I., and Pantano, J. (2013). Catastrophic natural disasters and economic growth. Review of Economics and Statistics, 95(5):1549-1561.

Cooper, R., Meyer, M., and Schott, I. (2017). The employment and output effects of short-time work in Germany. Technical report, National Bureau of Economic Research. Retrieved from: https://www.nber.org/papers/w23688.pdf.

Crespo Cuaresma, J., Hlouskova, J., and Obersteiner, M. (2008). Natural disasters as creative destruction? Evidence from developing countries. Economic Inquiry, 46(2):214-226.

Crimmann, A., Wießner, F., Bellmann, L., et al. (2010). The German work-sharing scheme: An instrument for the crisis. ILO.

Czech Hydrometeorological Institute (2014). Vyhodnocení povodní v červnu 2013: Závěrečná souhrnná zpráva [Evaluation of the flood in June 2013: Final summary report]. Technical report, Czech Hydrometeorological Institute. Retrieved from: http://voda.chmi.cz/pov13/SouhrnnaZprava.pdf.

Deeke, A. (2005). Kurzarbeit als Instrument betrieblicher Flexibilität: Ergebnisse aus dem IAB-Betriebspanel 2003 [Short-time work as an instrument of operational flexibility: Results from the IAB Establishment Panel 2003]. 
Technical report, Institut für Arbeitsmarkt- und Berufsforschung der Bundesagentur für Arbeit (IAB). Retrieved from: https://www.ssoar.info/ssoar/ bitstream/handle/document/31587/ssoar-2005-deeke-Kurzarbeit_als_

Instrument_betrieblicher_Flexibilitat.pdf?sequence=1\&isAllowed=y\&

lnkname=ssoar-2005-deeke-Kurzarbeit_als_Instrument_betrieblicher_

Flexibilitat.pdf.

Diamond, P. A. (1982). Aggregate demand management in search equilibrium. Journal of political Economy, 90(5):881-894.

Dustmann, C., Fitzenberger, B., Schönberg, U., and Spitz-Oener, A. (2014). From sick man of Europe to economic superstar: Germany's resurgent economy. Journal of Economic Perspectives, 28(1):167-88.

Eurofound (2010a). Extending flexicurity - The potential of short-time working schemes. Technical report, European Foundation for the Improvement of Living and Working Conditions. Retrieved from: https://www.eurofound.europa.eu/ sites/default/files/ef_publication/field_ef_document/ef1071en.pdf.

Eurofound (2010b). Flexibility profiles of European companies: European company survey 2009. Technical report, European Foundation for the Improvement of Living and Working Conditions. Retrieved from: https://www.eurofound. europa.eu/publications/report/2010/working-conditions-business/ flexibility-profiles-of-european-companies.

European Commission (2013). State aid SA.36861 (2013/NN) reimbursement of social contributions under short-time work for companies directly affected by the floods of May/June 2013 - Germany. Technical report, European Commission, Brussels. Retrieved from: https://ec.europa.eu/competition/elojade/isef/ case_details.cfm?proc_code=3_SA_36861.

European Commission (2015). Report from the Commission to the European Parliament and the Council: European Union Solidarity Fund annual report 2013. Technical report, European Commission. Re- 
trieved from: https://eur-lex.europa.eu/resource.html?uri=cellar: 5cebbc65-c70e-11e4-bbe1-01aa75ed71a1.0006.01/DOC_1\&format=PDF.

European Commission (2018). Ex-post evaluation of the European Union Solidarity Fund 2002-2016: Case study - Austria. Technical report, European Commission. Retrieved from: https://ec.europa.eu/regional_policy/sources/docgener/ evaluation/pdf/eusf_2002_2016/eusf_2002_2016_at_case_en.pdf.

Ewing, B. T., Kruse, J. B., and Thompson, M. A. (2009). Twister! Employment responses to the 3 May 1999 Oklahoma City tornado. Applied Economics, 41(6):691702.

Felbermayr, G. and Gröschl, J. (2014). Naturally negative: The growth effects of natural disasters. Journal of Development Economics, 111:92-106.

Fournier Gabela, J. G. and Sarmiento, L. (2020). The effects of the 2013 floods on Germany's freight traffic. Transportation Research Part D: Transport and Environment, page 102274 .

Fuchs, J., Hummel, M., Klinger, S., Spitznagel, E., Wanger, S., and Zika, G. (2010). Prognose 2010/2011: Der Arbeitsmarkt schließt an den vorherigen Aufschwung an [Forecast 2010/2011: The labor market will follow the previous upswing]. Technical report, Institute for Employment Research (IAB). Retrieved from: https://www. econstor.eu/bitstream/10419/158335/1/kb2010-18.pdf.

Gelman, A. and Imbens, G. (2019). Why high-order polynomials should not be used in regression discontinuity designs. Journal of Business \& Economic Statistics, 37(3):447-456.

Grainger, C. A. and Costello, C. J. (2014). Capitalizing property rights insecurity in natural resource assets. Journal of Environmental Economics and Management, 67(2):224-240.

Hausman, C. and Rapson, D. S. (2018). Regression discontinuity in time: Considerations for empirical applications. Annual Review of Resource Economics, 10:533-552. 
Hernanz, V., Malherbet, F., and Pellizzari, M. (2004). Take-up of welfare benefits in OECD countries: A review of the evidence. Technical report, OECD. Retrieved from: https://www.oecd.org/social/soc/30901173.pdf.

Hijzen, A. and Martin, S. (2013). The role of short-time work schemes during the global financial crisis and early recovery: A cross-country analysis. IZA Journal of Labor Policy, 2(1):5.

Hijzen, A. and Venn, D. (2011). The role of short-time work schemes during the 2008-09 recession. Technical report, Organisation for Economic Cooperation and Development (OECD). OECD social, employment, and migration working paper No. 115. Retrieved from: http://praha.vupsv.cz/fulltext/ul_1302.pdf.

Hoffmann, F. and Lemieux, T. (2016). Unemployment in the Great Recession: A comparison of Germany, Canada, and the United States. Journal of Labor Economics, 34(S1):S95-S139.

Hungarian Statistical Office (2020). Hungarian statistical office. Data retrieved from, https://www.ksh.hu/docs/hun/xstadat/xstadat_evkozi/e_qlf027e.html.

ICPDR (2014). Floods in June 2013 in the Danube river basin: Brief overview of key events and lessons learned. Technical report, International Commission for the Protection of the Danube River. International Commission for the Protection of the Danube River (ICPDR). Retrieved from: https://www.icpdr.org/main/sites/ default/files/nodes/documents/icpdr_floods-report-web_0.pdf.

in den Bäumen, H. S., Toebben, J., and Lenzen, M. (2015). Labour forced impacts and production losses due to the 2013 flood in Germany. Journal of hydrology, 527:142-150.

IPCC (2012). Managing the risks of extreme events and disasters to advance climate change adaptation: Special report of the Intergovernmental Panel on Climate Change. Cambridge University Press. (C. B. Field, V. Barros, T. F. Stocker, \& Q. Dahe, Eds.). 
Jongman, B., Hochrainer-Stigler, S., Feyen, L., Aerts, J. C., Mechler, R., Botzen, W. W., Bouwer, L. M., Pflug, G., Rojas, R., and Ward, P. J. (2014). Increasing stress on disaster-risk finance due to large floods. Nature Climate Change, 4(4):264268.

Khazai, B., Bessel, T., Möhrle, S., Dittrich, A., Schröter, K., Mühr, B., Elmer, F., Kunz-Plapp, T., Trieselmann, W., and Kunz, M. (2013). June 2013 flood in Central Europe - Focus Germany. Report 2 - Update 1: Impact and management. Technical report, Center for Disaster Management and Risk Reduction Technology (CEDIM). Retrieved from: https://www.cedim.kit.edu/download/ FDA-Juni-Hochwasser-Bericht2-ENG.pdf.

Leiter, A. M., Oberhofer, H., and Raschky, P. A. (2009). Creative disasters? Flooding effects on capital, labour and productivity within European firms. Environmental and Resource Economics, 43(3):333-350.

Loayza, N. V., Olaberria, E., Rigolini, J., and Christiaensen, L. (2012). Natural disasters and growth: Going beyond the averages. World Development, 40(7):13171336.

LOCZ (2014). Tisková zpráva [press release]. Labor Office of the Czech Republic. Retrieved from: http://obecstaremesto.cz/ projekt-mpsv-vzdelavejte-se-pro-stabilitu/d-3155.

McLaughlin, M. W. (1987). Learning from experience: Lessons from policy implementation. Educational evaluation and policy analysis, 9(2):171-178.

MEAE (2020). Employment service statistics. Ministry of Economic affairs and Employment (Finland). Data retrieved from: https://pxnet2.stat.fi/PXWeb/ pxweb/en/StatFin/StatFin__tym__tyonv/.

Messenger, J. C. (2009). Work sharing: A strategy to preserve jobs during the global jobs crisis. Travail Policy Brief $n, 1$.

Messenger, J. C. and Ghosheh, N. (2013). Work sharing during the Great Recession: New developments and beyond. Edward Elgar Publishing. 
MLSACZ (2012). Projekt "vzdělávejte se pro stabilitu" aneb kurzarbeit po česku [Project "educate yourself for stability" or kurzarbeit in czech]. Ministry of Labour and Social Affairs of the Czech Republic. Retrieved from: https://www.mpsv.cz/ -/projekt-vzdelavejte-se-pro-stabilitu-aneb-kurzarbeit-po-cesku.

MLSACZ (2020). Ministry of labour and social affairs of the czech republic. Data retrieved from, https://www.mpsv.cz/web/cz/mesicni.

MLSAF (2020). Reakcia na článok "vláda ignoruje snahy o kurzarbeit" [response to "government ignores kurzarbeit efforts"]. Ministry of Labor, Social Affairs and Family of the Slovak Republic. Accessed April 23, 2020. Retrieved from: https://www.employment.gov.sk/sk/informacie-media/ aktuality/reakcia-clanok-vlada-ignoruje-snahy-kurzarbeit.html.

MLSAFSK (2020). Ministry of labor, social affairs and family of the slovak republic. Data retrieved from, https://www.upsvr.gov.sk/statistiky/ nezamestnanost-mesacne-statistiky.html?page_id=1254.

Möller, J. (2010). The German labor market response in the world recession-demystifying a miracle. Zeitschrift für Arbeitsmarktforschung, 42(4):325-336.

Mortensen, D. T. and Pissarides, C. A. (1994). Job creation and job destruction in the theory of unemployment. Review of Economic Studies, 61(3):397-415.

Munich RE (2014). TOPICS GEO: Natural catastrophes 2013: Analyses, assessments, positions. Technical report, Munchener Ruckversicherungs-Gesellschaft. Retrieved from: https://www.munichre.com/content/dam/munichre/global/ content-pieces/documents/302-08121_en.pdf/_jcr_content/renditions/ original./302-08121_en.pdf.

Nagl, I., Bösch, V., Jandl-Gartner, T., and Schweighofer, J. (2019). Aktive Arbeitsmarktpolitik in Österreich 2014 - 2019: Dokumentation [Active labor market policy in Austria 2014-2019: Documentation]. Technical report, Bundesministerium für Arbeit, Soziales, Gesundheit und Konsumentenschutz (BMASGK). Bundesministerium für Arbeit, Soziales, Gesundheit und Konsumentenschutz (BMASGK). 
Retrieved from: https://broschuerenservice.sozialministerium.at/Home/ Download?publicationId=447.

Niederösterreichische Nachrichten (2013). Kurzarbeit als Wirtschaftshilfe nach Hochwasser [Short-time work as economic aid after floods]. Accessed June 3, 2020. Retrieved from: https://www.noen.at/niederoesterreich/wirtschaft/ kurzarbeit-als-wirtschaftshilfe-nach-hochwasser-arbeit-hochwasser-oesterreich-496

OECD (2010). OECD Employment Outlook 2010: Moving beyond the jobs crisis. "OECD Publishing. Retrieved from: https://www.oecd-ilibrary.org/content/ component/empl_outlook-2010-2-en.

ONS (2020). Annual population survey. Office for National Statistics (UK). Data retrieved from: https://www.nomisweb.co.uk/query/select/ getdatasetbytheme. asp?collapse=yes.

Oosterhaven, J. and Többen, J. (2017). Wider economic impacts of heavy flooding in Germany: A non-linear programming approach. Spatial Economic Analysis, 12(4):404-428.

Policelli, F., Slayback, D., Brakenridge, B., Nigro, J., Hubbard, A., Zaitchik, B., Carroll, M., and Jung, H. (2017). The NASA global flood mapping system. In Remote Sensing of Hydrological Extremes, pages 47-63. Springer.

Rinne, U. and Zimmermann, K. F. (2012). Another economic miracle? The German labor market and the Great Recession. IZA journal of labor policy, 1(1):3.

Sacchi, S., Pancaldi, F., and Arisi, C. (2011). The economic crisis as a trigger of convergence? Short-time work in Italy, Germany and Austria. Social Policy \& Administration, 45(4):465-487.

Schneider, S. and Graef, B. (2010). Germany's jobs miracle: Short-time work, flexible labour contracts and healthy companies. Technical report, Deutsche Bank Research. Retrieved from: https://de.scribd.com/document/30572425/ Germanys-Jobs-Miracle-Short-Time-Work-Flexible-Labour-Contracts-and-Healthy-Compa 
Suschitz, S. C. (2010). Kurzarbeit. PhD thesis, University of Vienna. Retrieved from: http://othes.univie.ac.at/9153/1/2010-01-27_0301915.pdf.

Thieken, A. H., Bessel, T., Kienzler, S., Kreibich, H., Müller, M., Pisi, S., Schröter, K., et al. (2016). The flood of june 2013 in Germany: How much do we know about its impacts. Nat. Hazards Earth Syst. Sci, 16(6):1519-1540.

Tiroler Tageszeitung (2013). Katastrophen-Kurzarbeit startet [Disaster short-time work starts]. Accessed June 1, 2020. Retrieved from: https://www.tt.com/ artikel/6686168/katastrophen-kurzarbeit-startet.

Toro, W., Tigre, R., and Sampaio, B. (2015). Daylight saving time and incidence of myocardial infarction: Evidence from a regression discontinuity design. Economics Letters, 136:1-4.

UPSVR (2012). Príspevok na podporu udržania pracovných miest ss $50 \mathrm{k}$ [Contribution to support the maintenance of jobs - ss 50k]. Central Office of Labour, Social Affairs and Family (Slovakia). Retrieved from: https://www.upsvr.gov.sk/sluzby-zamestnanosti/ nastroje-aktivnych-opatreni-trhu-prace/prispevky-pre-zamestnavatela/ prispevok-na-podporu-udrzania-pracovnych-miest-50k.html?page_id= 292635.

Van Audenrode, M. A. (1994). Short-time compensation, job security, and employment contracts: Evidence from selected OECD countries. Journal of Political Economy, 102(1):76-102.

Venn, D. (2012). Helping displaced workers back into jobs after a natural disaster: Recent experiences in OECD countries. Technical report, Organisation for Economic Cooperation and Development (OECD). OECD social, employment, and migration working paper No. 142. Retrieved from: https://pdfs.semanticscholar.org/ dd46/30d2d15d2379fc0fabf64b8c42c8888db5dc.pdf.

Xiao, Y. and Feser, E. (2014). The unemployment impact of the 1993 US Midwest 
983 flood: A quasi-experimental structural break point analysis. Environmental Hazards, $984 \quad 13(2): 93-113$. 


\section{A Appendix: Initial labor market equilibrium}

In the model, the creation of matches $m(u, v)$ depends on a traditional Cobb-Douglas constant returns to scale matching function on the vacancy rate $v$ and the unemployment rate $u$. The flow probability of matches for the job seeker and the company are equivalent to $\lambda_{w}=m(u, v) / u=\theta q(\theta)$ and $\lambda_{f}=m(u, v) / v=q(\theta)$, where $\theta$ is the parameter of market tightness (fraction of vacancies over unemployed persons $\theta=v / u)$. The time evolution of unemployed persons in the economy is given by $\dot{u}=\lambda F(\underline{\gamma}) \cdot(1-u)-\lambda_{w} \cdot u$, with existing matches endogenously separating at rate $\lambda F(\underline{\gamma})$, and new associations happening at rate $\lambda_{w}$. Equation A.1 shows the steady state version of the equation. Note how disaster shocks shift the Beveridge curve outward.

$$
u=\frac{\lambda F(\underline{\gamma})}{\lambda F(\underline{\gamma})+\lambda_{w}}
$$

6 Equation A.2 shows the present discounted value of a job, which depends on productivity, total wage paid $\omega(h, \gamma) \cdot h$, and the job's surplus depending on the expected job value $E(J)=\int_{\underline{\gamma}}^{\tilde{\gamma}} J(x) d F(x) . r$ stands for the exogenous real interest rate. Note that the job's value depends on the disaster shock $\gamma$, which directly affects productivity: the larger the value of $\gamma$, the lower the firm's value. Equation A.3 shows the first-order-condition (FOC) of this equation concerning the intensive margin of labor demand $(h)$. This equation shows that the firm chooses the optimal number of laborhours by subtracting from the marginal increase in productivity the marginal cost of paying this extra hour to the matched employee.

$$
\begin{gathered}
r J(\gamma)=(1-\gamma) \cdot p(h)-\omega(h, \gamma) \cdot h+\lambda[E(J)-J(\gamma)] \\
(1-\gamma) \cdot p_{h}(h)-\omega_{h}(h, \gamma) \cdot h-\omega(h, \gamma)=0
\end{gathered}
$$


Equation A.4 shows the present discounted value of an unmatched firm (vacancy), where $c$ is the cost of actively looking for a worker, and $\lambda_{f}(J(\gamma)-V)$ the probability of finding a match multiplied by the job's surplus. A company will keep its job offer open as long as $r V \geq 0$. Contrary, the firm will close and leave the matching pool.

$$
r V=-c+\lambda_{f}(J(\underline{\gamma})-V)
$$

Equations A.5 and A.6 show the value functions for employed and unemployed persons. The present discounted value of an employed person depends on the wage $\omega(h, \gamma)$, the number of working hours $h$, the disutility of labor $\Omega(h)$, and the worker's surplus depending on the expected value of being employed $E(W)=\int_{\underline{\gamma}}^{\tilde{\gamma}} W(x) d F(x)$. For the unemployed person, the value function depends on its income from unemployment benefits $b$, and the worker's surplus times the job-finding probability rate.

$$
r W(\gamma)=\omega(h, \gamma) \cdot h-\Omega(h)+\lambda[E(W)+F(\underline{\gamma}) U-W(\gamma)]
$$

$$
r U=b+\lambda_{w}(W(\underline{\gamma})-U)
$$

Traditionally, search and matching literature settles salaries with a straightforward Nash bargaining rule. This rule emerges because both firms and workers create bilateral monopolies by bargaining over the match quasi-rents. Equation A.7 shows the bargaining rule, where individuals and firms share the surplus from matching according to the worker's bargaining power $\beta$.

$$
(1-\beta)(W(\gamma)-U)=\beta(J(\gamma)-V)
$$

$$
\text { By substituting in this equation the previous value functions and using the free- }
$$


entry conditions requiring that $V=0$, we obtain wage-setting equation A.8. Note that as $\gamma$ increases, wages fall. According to this equation, when the disaster causes a productivity shock, the worker would earn a new wage $\omega^{\gamma}<\omega$. The reduction from $\omega$ to $\omega^{\gamma}$ entails match destruction because, for a share of workers, the outside option is now more attractive. Moreover, for firms unable to reduce wages due to wage rigidities, the only option is to destroy labor agreements.

$$
\omega(h, \gamma) \cdot h=\beta[(1-\gamma) \cdot p(h)+\theta c]+(1-\beta)(b+\Omega(h)))
$$

Equation A.9 shows the optimal level of hours, after substituting the wage equation on the first-order condition of the firm's value function regarding working hours (Eq. A.3) and assuming that $p(h)=h^{\alpha}$ with $0<\alpha<1$. Note that the intensive margin of labor also depends on the disaster shock: the greater the shock, the lower the number of optimal hours $h_{\gamma}^{*}<0$.

$$
h^{*}=\left[\frac{\Omega_{h}(h)}{\alpha(1-\gamma)}\right]^{\frac{1}{\alpha-1}}
$$

To derive the equilibrium values for job creation and the firing threshold, we plug in the equilibrium wage in the job value function, compute $J(\gamma)-J(\tilde{\gamma})=0$, use the freeentry condition $V=0$ and the job destruction condition $J(\tilde{\gamma})=0$, and evaluate the expressions at $\gamma=\underline{\gamma}$. Equations A.10 and A.11 give the resulting conditions. Together, equations A.1, A.8, A.9, A.10, and A.11 characterize the labor market equilibrium.

$$
\begin{gathered}
\frac{(1-\beta)}{r+\lambda}(\tilde{\gamma}-\underline{\gamma}) p(h)=\frac{c}{\lambda_{f}} \\
\tilde{\gamma}=1-\frac{1}{p(h)}\left(b+\Omega(h)+\frac{\beta}{1-\beta} \theta c\right)+\frac{\lambda}{r+\lambda} \int_{\underline{\gamma}}^{\tilde{\gamma}}(\tilde{\gamma}-x) d F(x)
\end{gathered}
$$




\section{${ }_{1037}$ B Appendix: Results from placebo trials}

Table B.1: Regression discontinuity results for unemployment in unaffected nations

\begin{tabular}{lccc}
\hline & \multicolumn{3}{c}{ Discontinuity : 2013 European Floods } \\
\cline { 2 - 4 } & Finland & UK-EWNI & Scotland \\
& $\Delta \ln$ Unemployment & $\Delta \ln$ Unemployment & $\Delta \ln$ Unemployment \\
\hline Robust Bias Corrected (RBC) & 0.01 & $-0.02^{* * *}$ & 0.06 \\
& $(0.01)$ & $(0.01)$ & $(0.04)$ \\
\hline Obs. to the Left & 152 & 333 & 64 \\
Obs. to the Right & 171 & 444 & 87 \\
Conventional Est. Bandwidth & 8.86 & 3.26 & 3.18 \\
Bias-Corrected Est. Bandwidth & 13.24 & 5.40 & 5.57 \\
\hline
\end{tabular}

Notes: ${ }^{* * *} p<0.001,{ }^{* *} p<0.01,{ }^{*} p<0.05$. This table contains the results from the augmented local linear regression discontinuity design on the rate of unemployment for Finland, UK-EWNI (England, Wales, and Northern Ireland), and Scotland. The discontinuity month is May 2013 for Finland and June 2013 for UK-EWNI and Scotland due to data limitations (quarterly unemployment). Standard errors are clustered at the county $\times$ month level. The order of the local-polynomial to construct the estimator (bias-correction) is 1 (2). The kernel function is triangular. 